\section{Arkivoc

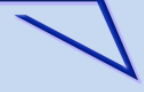

Archive for

Organic Chemistry
The Free Internet Journal

for Organic Chemistry
Review

Arkivoc 2019, part i, 304-339

\title{
Recent syntheses of steroidal derivatives containing heterocycles
}

\author{
Malika Ibrahim-Ouali*a ${ }^{a}$ d Frédéric Dumur ${ }^{b}$ \\ ${ }^{a}$ Aix Marseille Univ, CNRS, Centrale Marseille, iSm2, F-13397 Marseille, France \\ ${ }^{b}$ Aix Marseille Univ, CNRS, ICR, UMR 7273, F-13397 Marseille, France \\ Email address: malika.ibrahim@univ-amu.fr
}

Received 05-28-2019

Accepted 08-04-2019

Published on line 10-27-2019

\section{Abstract}

It was found that the introduction of a heterocycle or replacement by a heteroatom of one or more carbon atoms in the steroidal moiety could have a significant biological impact, and there has been much progress in the field of steroidal derivatives since. Recent developments in the syntheses of steroidal derivatives containing heterocycles are described herein.

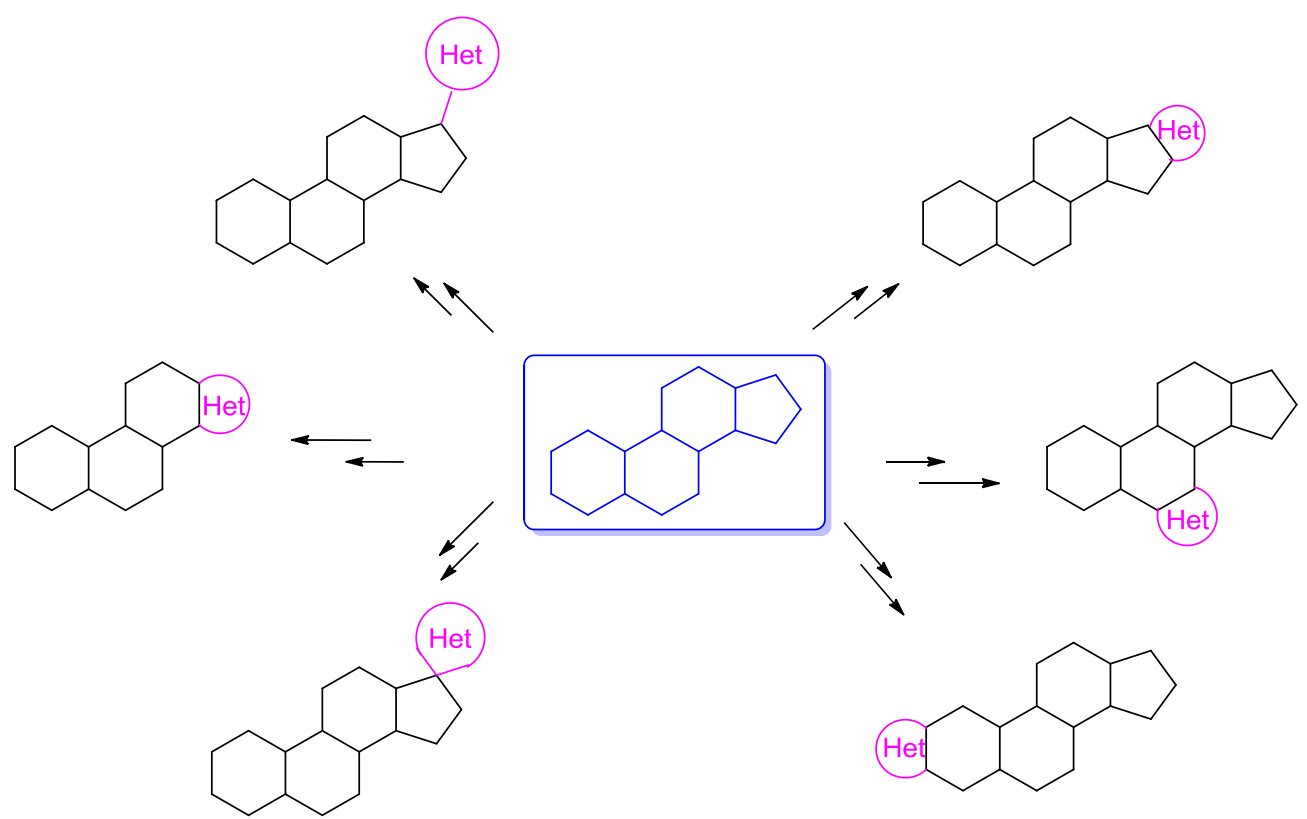

Keywords: Heterocycles, steroids, pyridines, thiazoles 


\section{Table of Contents}

1. Introduction

2. Synthesis of Steroidal Heterocycles

2.1 A-Ring fused steroidal heterocycles

2.2 B-Ring fused steroidal heterocycles

2.3 D-Ring fused steroidal heterocycles

3. Synthesis of Steroidal Derivatives Containing Heterocyclic Side-chains

4. Synthesis of Steroidal Spiro-heterocycles

5. Synthesis of Heterocyclic Steroidal Analogues

6. Conclusions

Acknowledgements

References

\section{Introduction}

Steroids constitute an extensive and important class of biologically active polycyclic compounds that are widely used for therapeutic purposes. ${ }^{1-3}$ Even after decades of research, the total synthesis of steroid nuclei by improved strategies continues to receive considerable attention. Numerous methods have been exploited for the total synthesis of steroids which are widely distributed in nature and which possess practical medical importance. Research into steroid total synthesis continues to this day. ${ }^{4,5}$

Heterocycles are widespread in drug molecules because they possess hydrogen bond donors and acceptors in a rigid framework, and they can therefore effectively interact with target enzymes and receptors via hydrogen bond interactions. They can enhance binding affinity and improve in vitro potency. Heterocycles can modulate the lipophilicity of the drug molecules or improve aqueous solubility of the compounds, thus providing desired pharmacokinetic and pharmacodynamic properties. ${ }^{6}$ Heterocyclic compounds are therefore widely applied in pharmaceutical and agrochemical research.

It was found that introducing heterocycles into steroids, ${ }^{7-12}$ by modification of the steroidal side chain or substitution of the steroidal skeleton, introducing a heteroatom or replacing one or more carbon atoms in steroidal molecule with a heteroatom, can result in a change in its biological activities. ${ }^{13-17}$ Steroids containing heteroatoms have been widely researched and reported. ${ }^{18}$ Literature reports have suggested that such compounds can display distinct cytotoxicity against cancer cell lines. ${ }^{19-22}$

This article provides an overview of the various synthetic strategies which have been employed to synthesize steroidal derivatives containing heterocycles along with interesting biological activities, from the years 2013-2019.

\section{Synthesis of Steroidal Heterocycles}

\subsection{A-Ring fused steroidal heterocycles}

In 2013, Dutta et al. ${ }^{23}$ developed a solventless one-pot reaction of a steroidal 1,5-diketo compound with urea employing $\mathrm{BF}_{3} . \mathrm{OEt}_{2}$ as the catalyst, for the synthesis of steroidal A- and D-ring fused 4,6-diarylpyridines under microwave irradiation. The intermediate steroidal 1,5-diketo compounds were synthesized by Michael addition reaction of steroidal ketones with enones in situ-generated from aromatic ketones and aldehydes (Scheme 1). The reaction of steroidal ketone 1 with a variety of aromatic aldehydes and aryl ketones including 
both electron-deficient and electron-rich groups was investigated. The 1,5-dicarbonyl compounds were obtained in excellent yields in all cases and no undesired side reactions were observed. In the next step, the cyclization reaction of the diketones $\mathbf{4}$ afforded steroidal pyridines $\mathbf{5}$ in excellent yields.

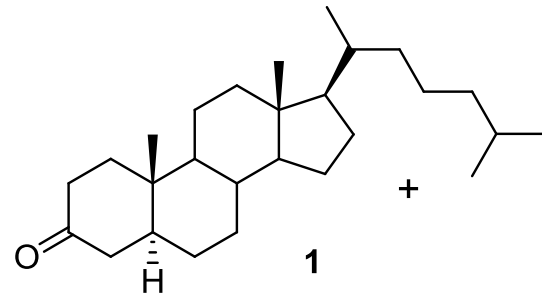

$4+\mathrm{H}_{2} \stackrel{\mathrm{N}}{\mathrm{O}}_{\mathrm{NH}_{2}}$<smiles>[R]C[O+]=[Co]</smiles>

3
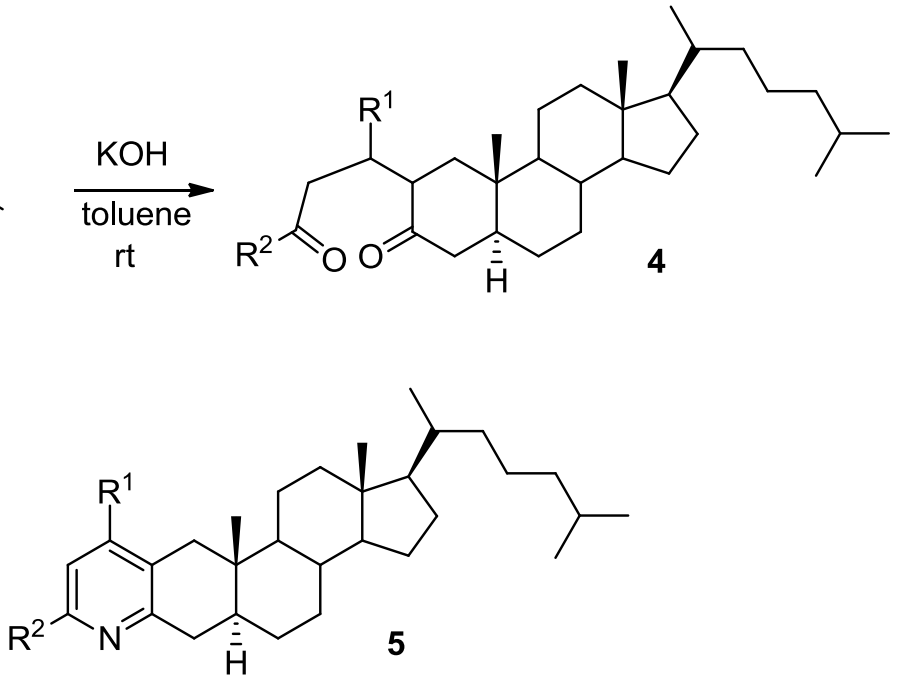

Scheme 1. Synthesis of 4',6'-diaryl-cholest[3,2-b]pyridine derivatives 5.

In 2013, the same authors developed a solvent-free multi-component reaction condition for the synthesis of steroidal A-ring fused 5,6-disubstituted pyridines using $\mathrm{Pd}(\mathrm{OAc})_{2}$ as the catalyst under microwave irradiation. ${ }^{24} \mathrm{~A}$ wide variety of alkyl-, aryl- and ester-substituted alkynes undergo this highly regioselective reaction to give good yields of pyridine derivatives. The starting material, the steroidal ?-bromovinyl aldehyde 6, was synthesized from commercially available 5? -cholestan-3-one by reaction with Vilsmeier reagent in refluxing chloroform. ${ }^{25} \mathrm{~A}$ mixture of steroidal ?-bromovinyl aldehyde 6 , benzylamine, alkyne 7, palladium acetate (5 mol\%), triphenylphosphine, $\mathrm{Na}_{2} \mathrm{CO}_{3}$ and neutral alumina was then irradiated in a closed vessel in a Synthos 3000 microwave reactor at 600 Watts for $10 \mathrm{~min}$, affording A-ring fused 5,6-disubstituted pyridines 8 (Scheme 2) in good yields. Instead of benzylamine, other amines such as tert-butylamine were tried, but a decreased yield of compound $\mathbf{8}$ was obtained, which could be due to the lower boiling point of tertbutylamine. They also observed that reducing the quantity of $\mathrm{Pd}(\mathrm{OAc})_{2}$ decreased the yield of 8 while increase of catalyst loading to 10 mol\% did not affect the yield of 8 at all.<smiles>CC(C)CCCC(C)[C@H]1CCC2C3CCC4CC(Br)=C(C=O)C[C@]4(C)C3CC[C@]21C</smiles>

6

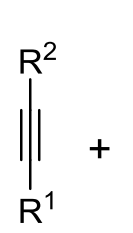

7

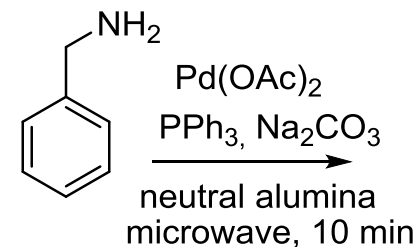
microwave, $10 \mathrm{~min}$

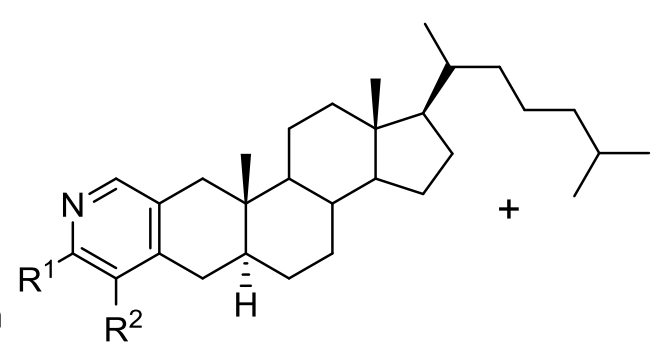

8

$$
\begin{aligned}
& \mathrm{R}^{1}=\mathrm{H}, \text { COOMe, Me, } \mathrm{Pr}, \mathrm{Si}\left(\mathrm{CH}_{3}\right)_{3} \\
& \mathrm{R}^{2}=\mathrm{H}, \mathrm{Ph}, \mathrm{F}-\mathrm{Ph}
\end{aligned}
$$

Scheme 2. Synthesis of steroidal A-ring fused substituted pyridines. 


\subsection{B-Ring fused steroidal heterocycles}

In 2017, Ali et al. ${ }^{26}$ prepared a series of novel steroidal pyrimidine derivatives via a multicomponent domino process. For the synthesis of steroidal pyrimidines 12-14, 3ㄱ-acetoxycholestan-6-one 9c, 3?-chlorocholestan-6one 10c, and 5?-cholestan-6-one 11c were synthesized by literature methods, ${ }^{27}$ and these were treated with urea and benzaldehyde in $\mathrm{DMF} / \mathrm{CH}_{3} \mathrm{CN}$ in the presence of $\mathrm{TMSCl}$ (used as promoter) under air; the reaction mixture was initially maintained at room temperature, and then warmed to $90{ }^{\circ} \mathrm{C}$ under reflux conditions (Scheme 3). The compounds $\mathbf{1 2 - 1 4}$ showed different cytotoxicity against three cancer cell lines.

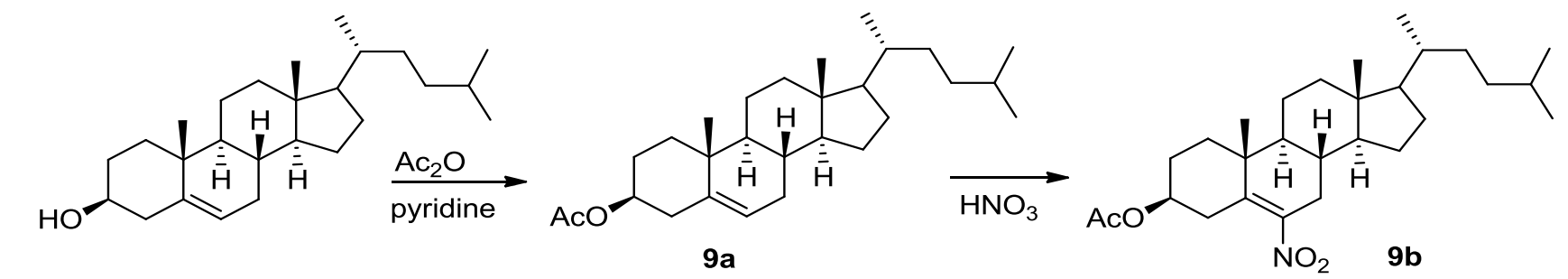

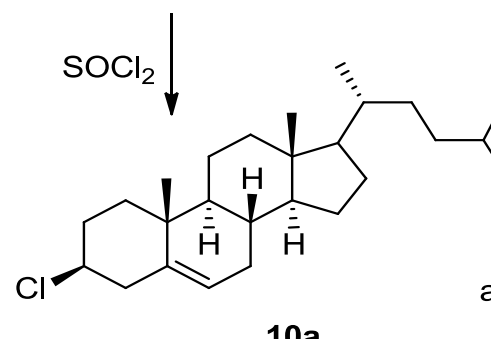

$10 a$
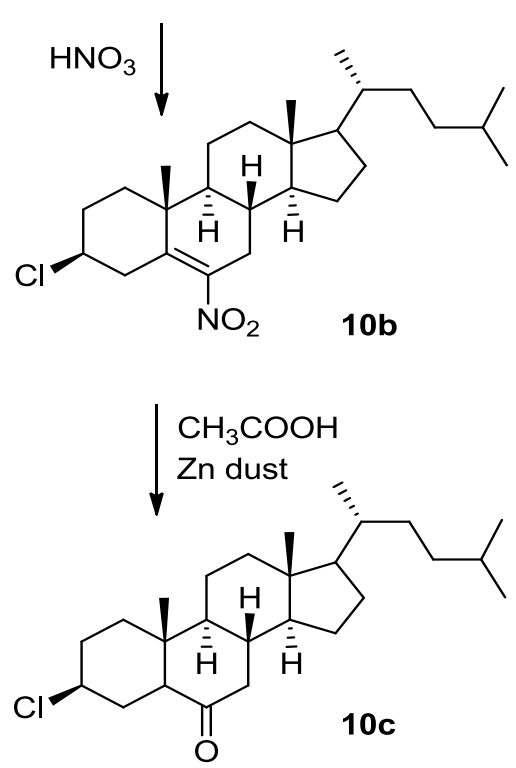

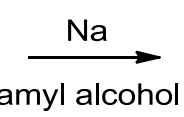

myl alcohol

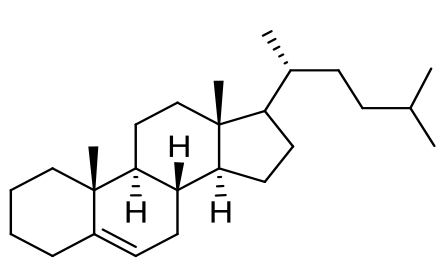

$11 \mathrm{a}$

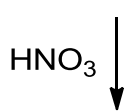<smiles>CC(C)CC[C@H](C)[C@H]1CC[C@H]2[C@H]3CC([N+](=O)[O-])=C4CCCC[C@]4(C)[C@H]3CC[C@@]21C</smiles><smiles>[Y][C@H](C)[C@@H](C)CCC(C)C</smiles>

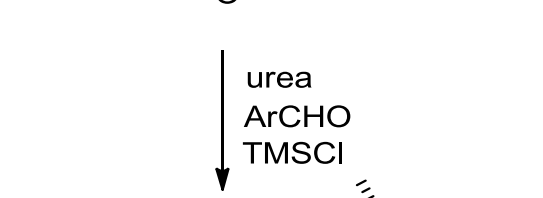<smiles>CC(=O)O[C@H]1CC[C@@]2(C)C(C1)c1nc(O)nc(-c3ccccc3)c1[C@@H]1[C@@H]2CC[C@]2(C)C([C@@H](C)CCC(C)C)CC[C@H]12</smiles>

12

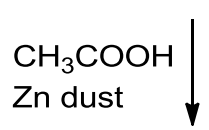

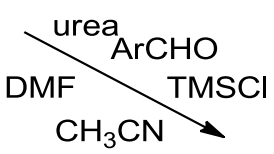<smiles>CC(C)CC[C@H](C)C1CC[C@H]2[C@H]3CC(=O)C4CCCC[C@]4(C)[C@H]3CC[C@]12C</smiles>

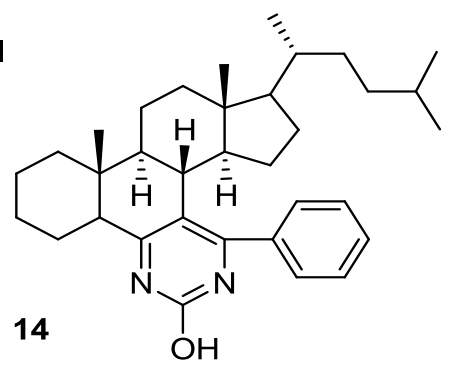<smiles>Oc1nccc(-c2ccccc2)n1</smiles>

13

Scheme 3. Synthetic pathway for the formation of B-ring-fused steroidal pyrimidines 12-14. 


\subsection{D-Ring fused steroidal heterocycles}

As described in Section 2.1, Dutta et al. ${ }^{24}$ developed a solvent free multi-component reaction process for the synthesis of steroidal A-ring fused 5,6-disubstituted pyridines. The same method was used for the synthesis of steroidal D-ring fused 5,6-disubstituted pyridines using $\mathrm{Pd}(\mathrm{OAc})_{2}$ as the catalyst under microwave irradiation. A steroidal ?-bromovinyl aldehyde $\mathbf{1 5}$ was synthesized starting commercially available 3-acetoxyandrost-5-en17-one by treatment with Vilsmeier reagent prepared from $\mathrm{PBr}_{3}$ and $\mathrm{DMF}^{25}$ Similarly, microwave reactions of steroidal ?-bromovinyl aldehyde 15 with alkynes 7 afforded steroidal D-ring fused substituted pyridines 16 in high yields (Scheme 4). In all of the reactions of ?-bromovinyl aldehydes with substituted alkynes and benzylamine under the reaction conditions described above (see 2.1), only one regioisomer of the pyridine derivative was obtained.

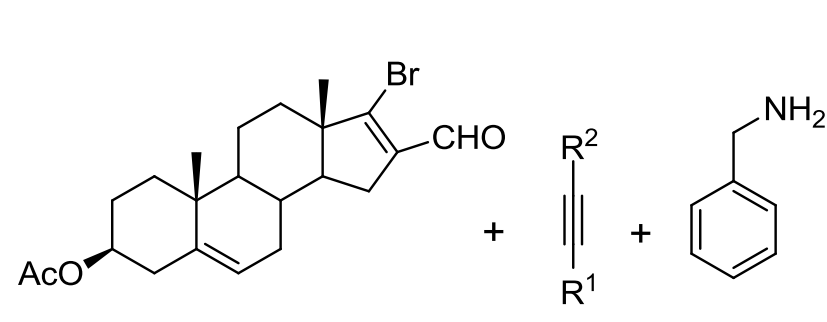

15

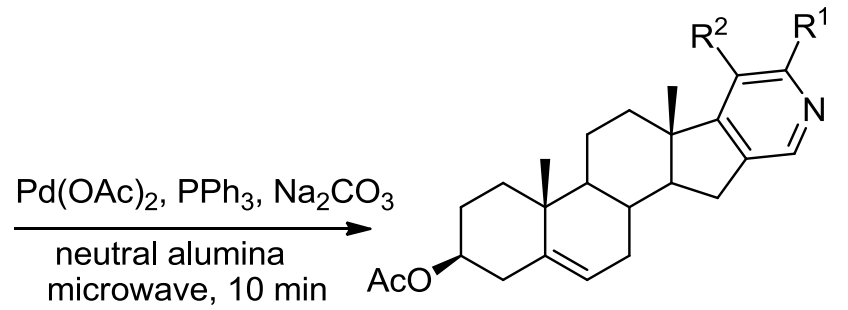

16

$$
\begin{aligned}
& \mathrm{R}^{1}=\mathrm{H}, \text { COOMe, Me, } \mathrm{Pr}, \mathrm{Si}\left(\mathrm{CH}_{3}\right)_{3} \\
& \mathrm{R}^{2}=\mathrm{H}, \mathrm{Ph}, \mathrm{F}-\mathrm{Ph}
\end{aligned}
$$

Scheme 4. Synthesis of steroidal D-ring fused pyridines.

In the same year, Zhang et al. ${ }^{28}$ developed a convenient synthesis of pure, air-stable steroidal D-ring fused pyridine compound 22, D-ring fused thiazole imines and reductive products 25 a-e and 26a-e, and D-ring fused imidazo[2,1-b]thiazole product $\mathbf{2 7}$ from readily available starting material dehydroepiandrosterone (DHEA) 17 (Schemes 5-7). This provided a simple strategy to synthesize steroids combined at the D-ring with heterocycles, extending the categories of heterosteroids. The strategy can be applied to diverse 3-or 17-ketosteroids and the steroidal thiazole-imines may allow further modification on the steroidal skeleton. They synthesized a series of D-ring fused pyridines with $\mathbf{1 7}$ as the starting material by the means of a Friedländer reaction (Scheme 5). Compound 18 was prepared by a standard procedure, by treating 17 with acetic anhydride catalyzed by DMAP with a good yield. Compound 19 was synthesized by a Vilsmeier reaction ${ }^{29}$ and compound $\mathbf{2 1}$ was also synthesized according to Staudinger's procedure by treating 20 with $\mathrm{Ph}_{3} \mathrm{P}$ in $\mathrm{THF} / \mathrm{H}_{2} \mathrm{O}$ (9:1). The yield was not very good (under 50\%). Compound 20 was synthesized by treating 19 with $\mathrm{NaN}_{3}$ in $\mathrm{DMF} / \mathrm{H}_{2} \mathrm{O}$. In the synthesis process of $\mathbf{2 2}$, when the base was replaced by $\mathrm{NaOH}$, only the deacetylation product was detected. When they tried to expand the series of $\mathbf{2 2}$ with various reactive methylene species, such as acetophenone, 4-methoxyacetophenone, ethyl cyanoacetate, ethyl chloroacetate, ethyl acetoacetate, or ethyl 4-chloroacetoacetate, no product was obtained with any of them. 
<smiles>CCOC(=O)COC(=O)OCC</smiles>

17<smiles>CC(=O)O[C@H]1CC[C@@]2(C)C(=CCC3C4CCC(=O)[C@@]4(C)CCC32)C1</smiles>

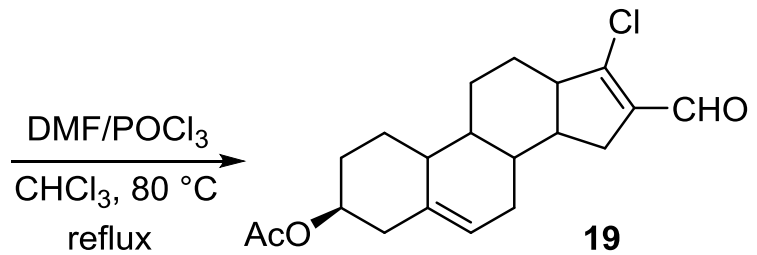

19

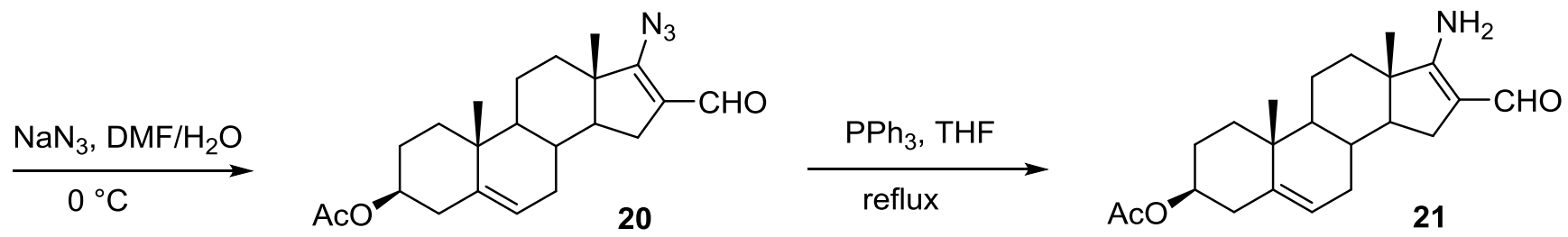

malonitrile, piperidine

EtOH, reflux<smiles>CC(=O)O[C@H]1CC[C@@]2(C)C(=CCC3C4Cc5cc(C#N)c(N)nc5[C@@]4(C)CCC32)C1</smiles>

Scheme 5. Synthesis of steroidal D-ring fused pyridines 22.

In 2011, Elmegeed ${ }^{30}$ reported that the first step can be done by using 3?-acetoxy-5?-androstan-17-one, which is similar to $\mathbf{1 8}$, as the starting material without losing the acetyl group under the same condition, followed by the next cyclization step in THF, and catalyzed by piperidine with a yield of $50 \%$. Their procedure here was carrying out this step in $\mathrm{EtOH}$ by using triethylamine as a catalyst with a yield over $50 \%$. With 24 in hand, they selected a benzaldehyde without an electron-withdrawing or electron-donating group as the first aldehyde, to carry out the next step to generate thiazolyl imines. Compounds 25a-e were purified by column chromatography and then treated with $\mathrm{NaBH}_{4}$ in $\mathrm{MeOH}$ to generate 26a-e (Scheme 6).

Scheme 7 outlines the synthetic procedures of compound $27{ }^{28}$ the measures to prepare 24 were identical to the ways of synthesizing D-ring fused thiazole imine and reductive products. $\mathbf{2 7}$ was synthesized by treating compound $\mathbf{2 4}$ with ethyl chloroacetate in DMF; it was characterized by 1D- and 2D-NMR spectroscopy. 
<smiles>[R]O[R]([R])=O</smiles>

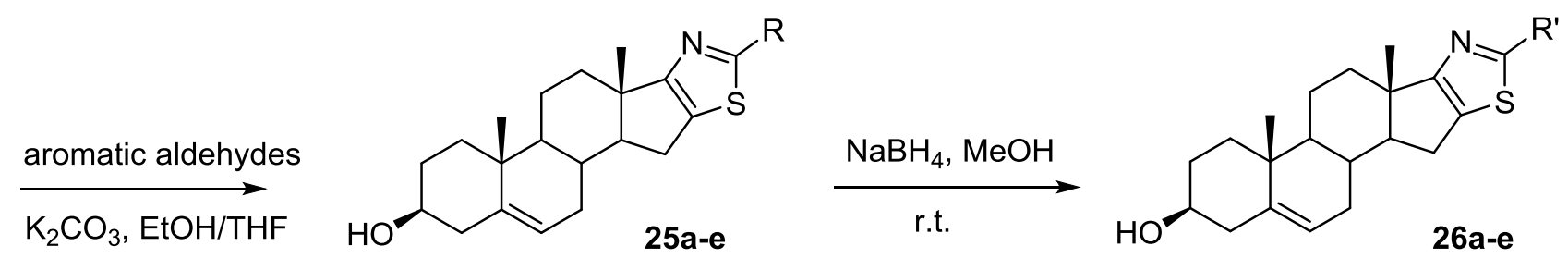
r.t., $-60^{\circ} \mathrm{C}$<smiles>[R]=[V]C=Nc1ccccc1</smiles>

a<smiles>Clc1ccc(N=C[V])cc1</smiles>

b<smiles>[V]=NCc1ccoc1</smiles>

c<smiles>CN=Cc1ccc2ccccc2c1</smiles><smiles>COc1cccc(C=NC(C)(F)F)c1</smiles><smiles>[R]=C=[V]NCc1ccccc1</smiles>

a<smiles>[Y]NCc1ccc(Cl)cc1</smiles>

b<smiles>NCc1ccoc1</smiles>

c<smiles>CNCc1ccc2ccccc2c1</smiles><smiles>COc1cccc(CNC(C)(F)F)c1</smiles>

Scheme 6. Synthesis of steroidal D-ring fused thiazole imine and reductive products.

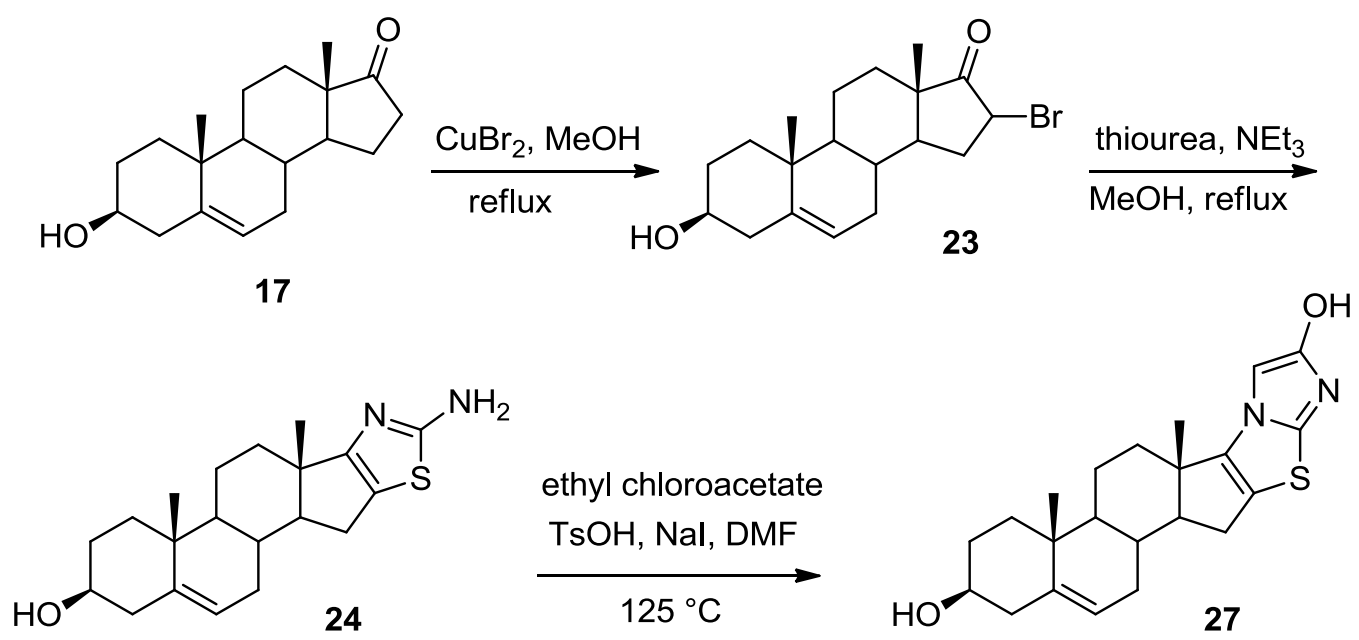

Scheme 7. Synthesis of steroidal D-ring fused imidazo[2,1-b]thiazole products.

In 2014, Zhang et al. ${ }^{31}$ developed convenient syntheses of steroidal [1,2-b]pyridine, [17,16- $d$ ]thiazole and $[17,16-d]$ thiazolo[2,1- $b]$ imidazole ring-fused analogues. After further exploration of the reaction conditions and reference to Wu's work, ${ }^{32}$ they completed the synthesis of compounds 28a-d (Scheme 8). 
<smiles>CC(=O)O[C@H]1CC[C@@]2(C)C(=CCC3C4CC(C=O)=C(N)C4(C)CCC32)C1</smiles>

21

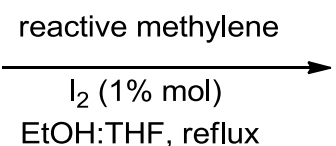

EtOH:THF, reflux

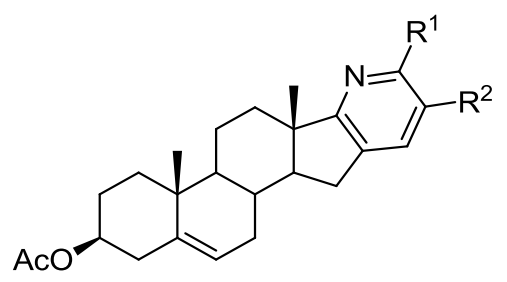

28a-d

$$
\begin{aligned}
& \text { 28a } R^{1}=\mathrm{CH}_{3}, R^{2}=\mathrm{CO}_{2} \mathrm{Et} \\
& \text { 28b } \mathrm{R}^{1}=\mathrm{CH}_{3}, \mathrm{R}^{2}=\mathrm{COCH}_{3} \\
& \text { 28c } \mathrm{R}^{1}=\mathrm{CH}_{2} \mathrm{Cl}, \mathrm{R}^{2}=\mathrm{CO}_{2} \mathrm{CH}_{3} \\
& \text { 28d } \mathrm{R}^{1}=\mathrm{CH}_{2} \mathrm{Cl}, \mathrm{R}^{2}=\mathrm{CO}_{2} \mathrm{Et}
\end{aligned}
$$

Scheme 8. Synthesis of steroidal D-ring fused pyridines $\mathbf{2 8 a - d .}$

The authors applied their protocol to the preparation of several new substituted aryl derivatives $\mathbf{2 9}$ and 30 (Scheme 9). These compounds were evaluated for their antiproliferation activity in vitro against EC109 (human esophageal carcinoma), EC9706 (human esophageal carcinoma) and MGC803 (human gastric carcinoma) cell lines. Bioactivity test results showed that compound $\mathbf{3 0}$ series have a relatively good activity against the three cell lines, especially the EC109 line. Both the synthesized compounds 28b-d, 29a-j and 30a-j are reported to have a good activity against the MGC803 cell line.

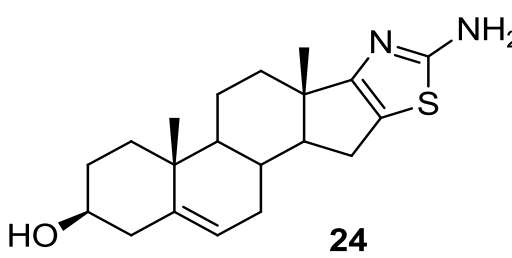

24

aromatic aldehydes $\mathrm{K}_{2} \mathrm{CO}_{3}, \mathrm{EtOH} / \mathrm{THF}$ r.t., $-60^{\circ} \mathrm{C}$

$\mathrm{NaBH}_{4}, \mathrm{MeOH}$ r.t.<smiles>[R]CNc1nc2c(s1)CC1C3CC=C4C[C@H](O)CC[C@]4(C)C3CC[C@@]21C</smiles><smiles>[R]=[W][14c]1[14cH][14cH][14cH][14cH][14cH]1</smiles>

a<smiles>CC=Cc1ccccc1</smiles>

f<smiles>Cc1ccc(Cl)cc1</smiles>

b<smiles>Nc1ccoc1</smiles>

c<smiles>[Y]c1cc[nH]c1</smiles>

g<smiles>[Y]c1ccccn1</smiles>

h<smiles>[R]C=Nc1nc2c(s1)CC1C3CC=C4C[C@@H](O)CC[C@]4(C)C3CC[C@]21C</smiles>

29a-j<smiles></smiles>

d<smiles>CC(C)c1ccc(C(C)(C)C)cc1</smiles>

$\mathbf{i}$<smiles>COc1cccc(C(F)(F)F)c1</smiles>

e<smiles>CC(C)(C)c1ccc(N2CCOCC2)cc1</smiles>

Scheme 9. Synthesis of steroidal thiazole imines and corresponding reduction products. 
<smiles>C[C@]12CC[C@H]3C(CC=C4C[C@@H](O)CC[C@]43C)C1CCC2=O</smiles>

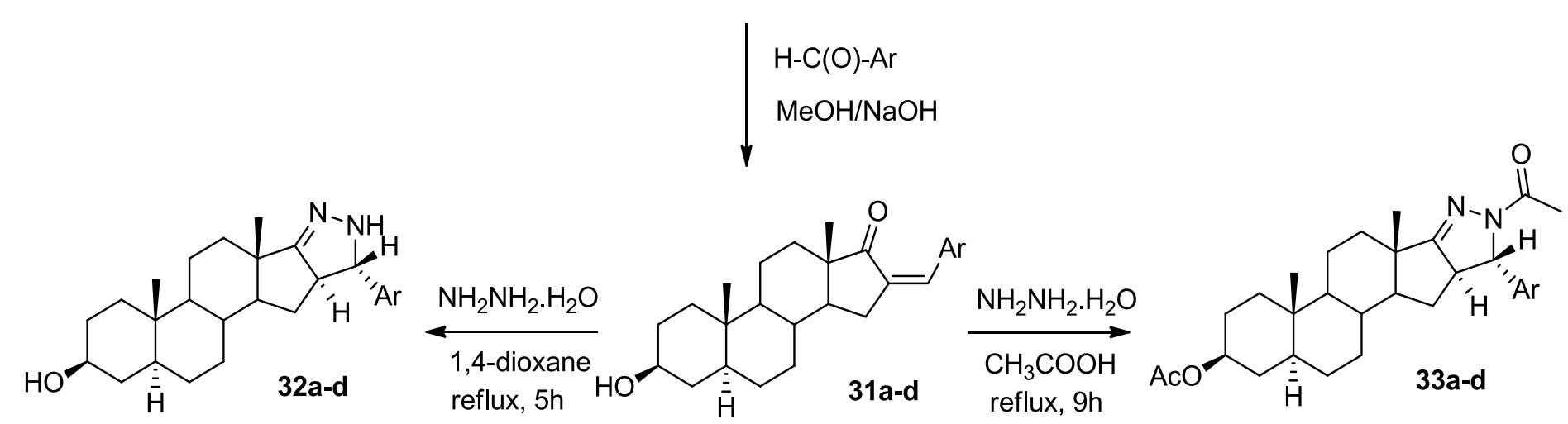<smiles>CO[14C](=O)c1ccccc1</smiles>

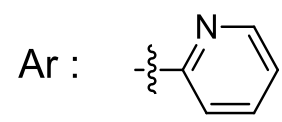

a<smiles></smiles>

b

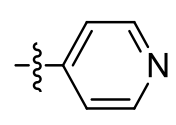

C

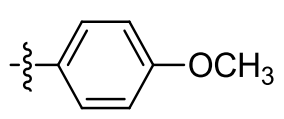

d

Scheme 10. Synthetic route to the formation of various 16,17-pyrazolo-steroids.

Anhydrous 1,4 dioxane and anhydrous methanol were found to be the most suitable solvents for the synthesis of pyrazolo-steroids. The compounds were purified by automated flash chromatography as they decompose while crystallizing in most solvents. Treatment with the pyrazoline substituted steroids considerably improved the LPS- induced learning, memory and movement deficits in animal models. Suppression of biochemical parameters of oxidative and nitrosative stress, acetylcholine esterase activity, and TNF- $\alpha$ levels was also observed. 16,17-Pyrazolo-steroids 32-34c substituted with a 4-pyridyl moiety at the 5position of the heterocyclic ring were found to be the most potent agents and produced neuroprotective effects better than standard drugs celecoxib and dexamethasone. Of these pyrazoline-substituted steroids, 
the $\mathrm{N}$-acetyl analogue 33c displayed better neuroprotective effects than $\mathrm{N}$-phenyl 34c, which in turn showed a higher potency than the $N$-unsubstituted analogue 32.

In 2019, Mohareb et al. ${ }^{36}$ synthesized a series of heterocyclic estrone derivatives. They investigated the Gewald reaction $^{37}$ of estrone $\mathbf{3 5}$ with cyanoacetylhydrazine $\mathbf{3 6}$ in ethanol and triethylamine which gave the thiophene derivative $\mathbf{3 7}$. The hydrazide group present in compound $\mathbf{3 7}$ reacted with acetophenone 38a, 4chloroacetophenone $\mathbf{3 8 b}$ or $\mathbf{4 - m e t h y l a c e t o p h e n o n e ~} \mathbf{3 8 c}$ to give the hydrazide-hydrazone derivatives $\mathbf{3 9 a - c}$ respectively (Scheme 11).<smiles>C[C@]12CC[C@H]3c4ccc(O)cc4CC[C@H]3[C@H]1CCC2=O</smiles>

35<smiles>C[C@@]12CC[C@H]3c4ccc(O)cc4CC[C@H]3[C@@H]1Cc1sc(N)c(C(=O)NN)c12</smiles>

37<smiles>CCOCCN(CC)CC[SbH2+]</smiles>
36<smiles>C[C@@]12CC[C@H]3c4ccc(O)cc4CC[C@H]3[C@@H]1Cc1sc(N)c(C(=O)NN)c12</smiles>

37

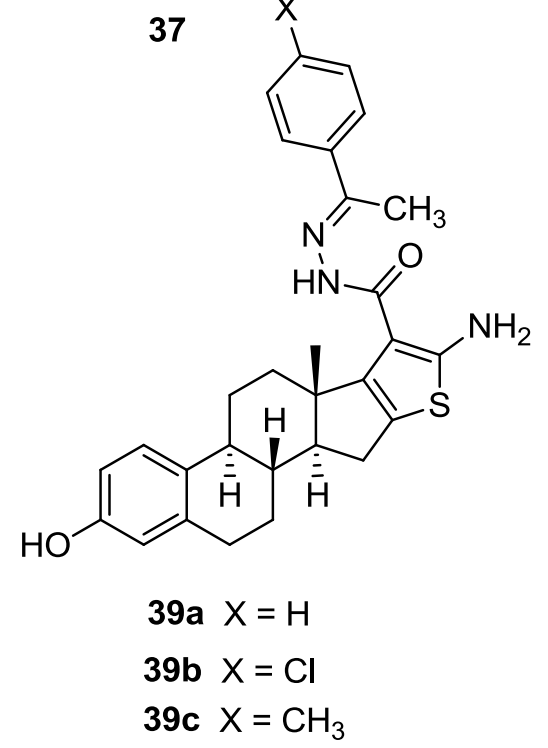

Scheme 11. Synthesis of compounds 37 and 39a-c.

The 2-amino group present in compound $\mathbf{3 7}$ is capable of amide formation. Thus, compound $\mathbf{3 7}$ reacted with ethyl cyanoacetate in dimethylformamide to afford the 2-cyanoacetamide derivative $\mathbf{4 0}$. Compound $\mathbf{4 0}$ reacted with phenyl isothiocyanate $\mathbf{4 1}$ to give the $\mathbf{N}$-phenylthiosemicarbazide derivative $\mathbf{4 2}$. Compound $\mathbf{4 2}$ reacted with either of ethyl chloroacetate $\mathbf{4 3 a}$ or $\alpha$-chloroacetone $\mathbf{4 3 b}$ to give the thiazole derivatives $\mathbf{4 4 a}$ and 44b, respectively (Scheme 12). 
<smiles>CCOC(=O)CC#N</smiles>

37<smiles>C[C@@]12CC[C@H]3c4ccc(O)cc4CC[C@H]3[C@H]1Cc1sc(NC(=O)CC#N)c(C(=O)NN)c12</smiles><smiles>[R]OC(=O)CCCl</smiles><smiles>C[C@]12CCC3c4ccc(O)cc4CC[C@H]3[C@@H]1Cc1sc(NC(=O)CC#N)c(C(=O)NN)c12</smiles>

40<smiles>C[C@@]12CCC3c4ccc(O)cc4CC[C@H]3[C@H]1Cc1sc(NC(=O)CC#N)c(C(=O)NNC(=S)Nc3ccccc3)c12</smiles>

42

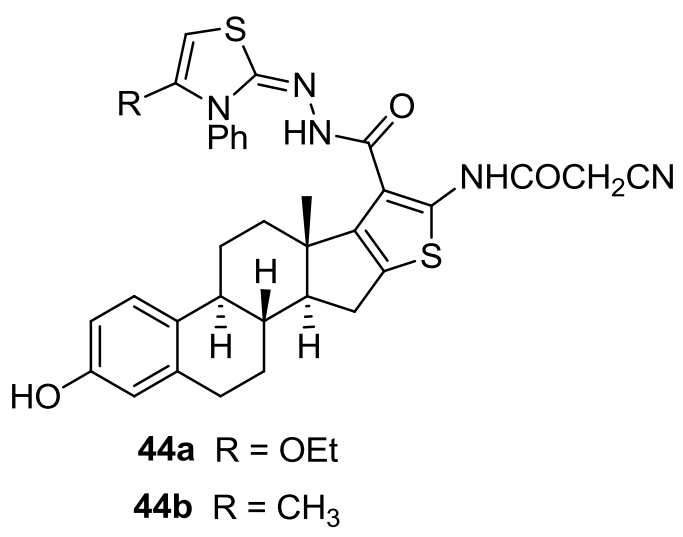

Scheme 12. Synthesis of compounds 40,42 and $44 a, b$.

The reaction of compound $\mathbf{4 2}$ with $\omega$-bromoacetophenone $\mathbf{4 5 a}$, 4-methyl- $\omega$-bromoacetophenone $\mathbf{4 5 b}$ or 4-chloro- $\omega$-bromoacetophenone $\mathbf{4 5 c}$ gave the thiazole derivatives $\mathbf{4 6 a - c}$, respectively. Compound $\mathbf{4 0}$ reacted with any of benzenediazonium chloride 47a, 4-methylbenzenediazonium chloride 47b, 4chlorobenzenediazonium chloride $\mathbf{4 7 c}$ or 4-methoxybenzenediazonium chloride $\mathbf{4 7 d}$ to give the arylhydrazone derivatives $\mathbf{4 8 a - d}$, respectively. On the other hand, the reaction of compound $\mathbf{4 0}$ with either of malononitrile 49a or ethyl cyanoacetate $49 \mathrm{~b}$ in refluxing ethanol containing triethylamine gave the pyridine derivatives 50a and 50b, respectively (Scheme 13). The nine compounds 39, 39c, 44a, 46c, 48b, 48c, 48d, 50a and 50b showed the highest potency against c-Met kinase and six cancer cell lines. These compounds were investigated against the five tyrosine kinases c-Kit, Flt-3, VEGFR-2, EGFR, and PDGFR where compound 50b showed the highest inhibitory effect. Compounds 39b, 48d, 50a and 50b were selected to examine their Pim-1 kinase inhibition activity where compounds $\mathbf{4 8 d}$ and $\mathbf{4 8 b}$ were the most active compounds. The toxicity against shrimp larvae revealed that compounds $\mathbf{3 9 b}, \mathbf{4 6 c}, \mathbf{4 8 c}, \mathbf{4 8 d}$ and $\mathbf{5 0 a}$ were non-toxic against the tested organisms. 


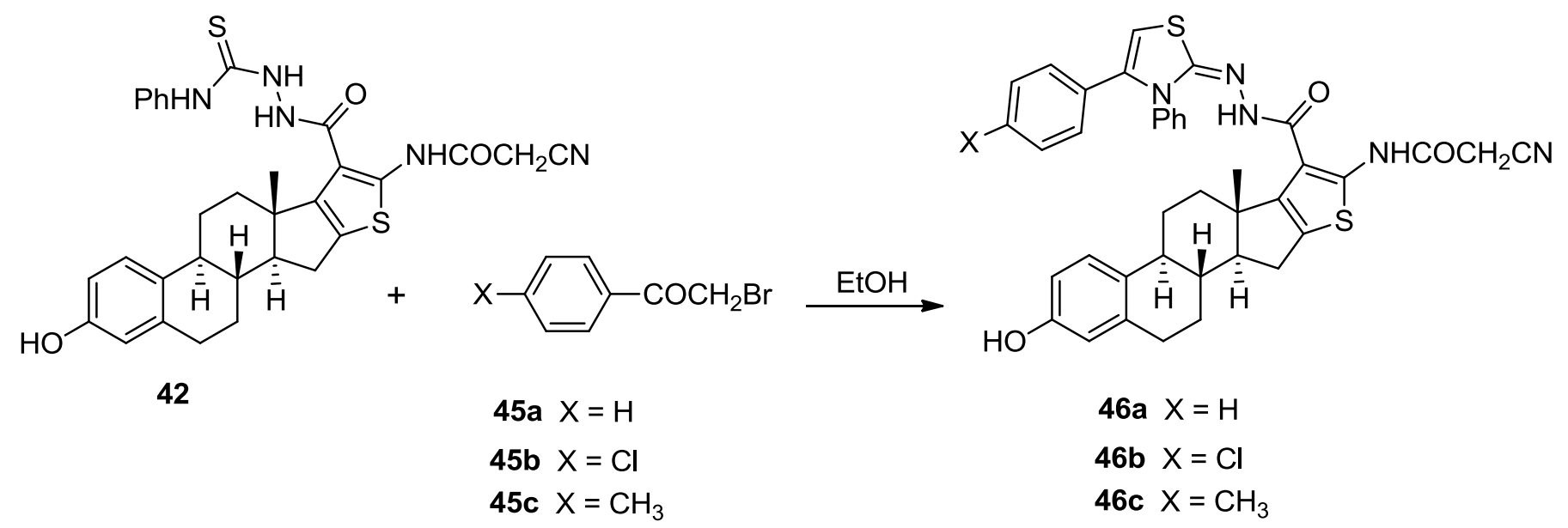

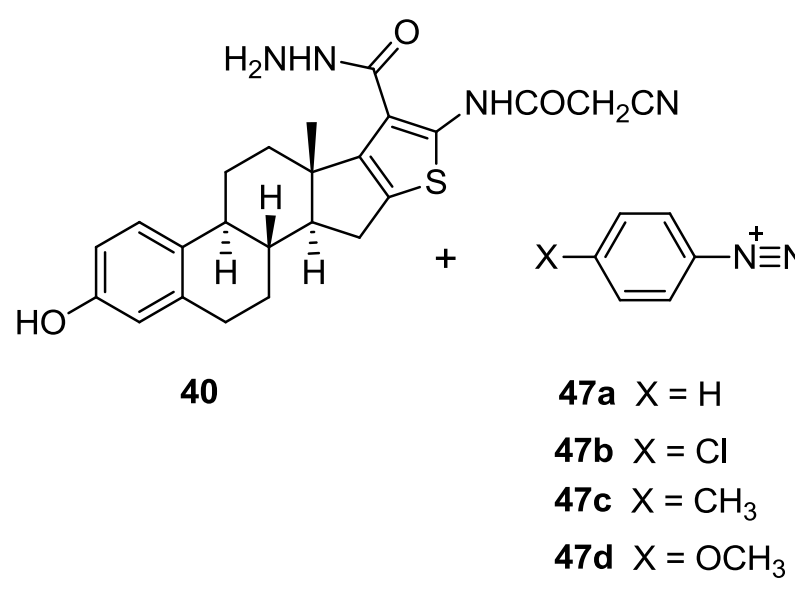

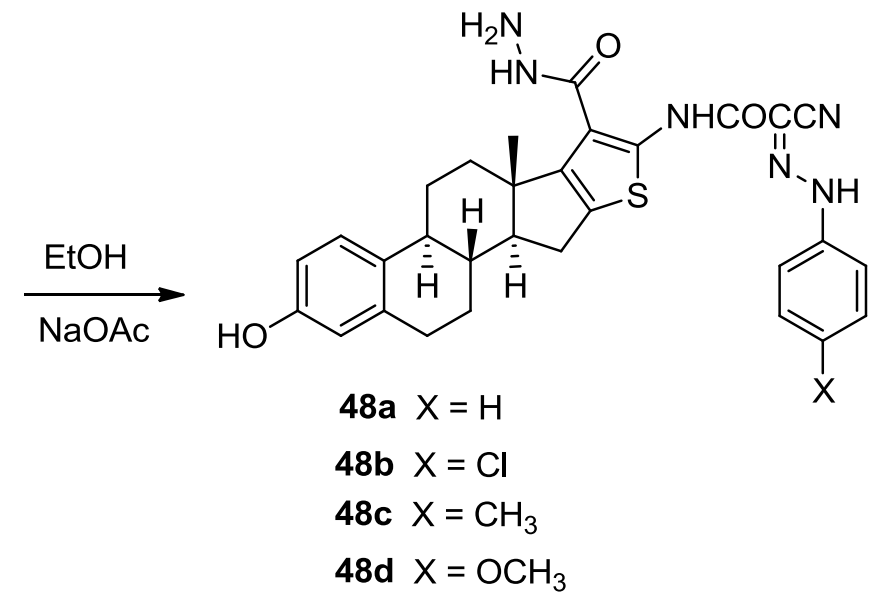

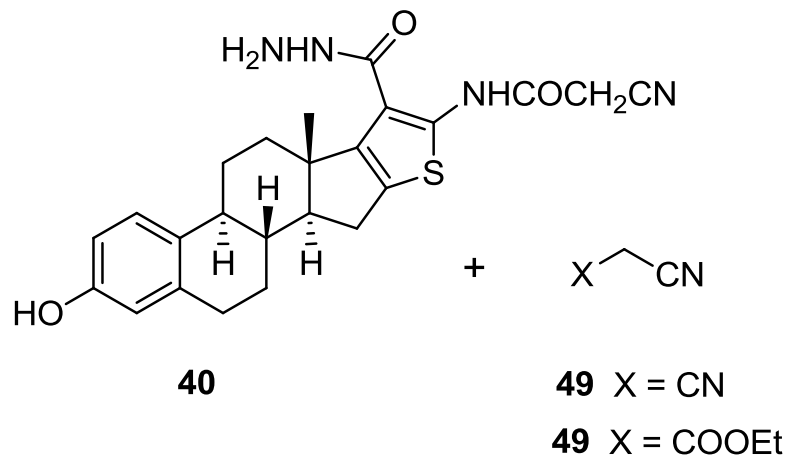<smiles>[R]c1cc(N)c(C#N)c(=O)n1-c1sc2c(c1C(=O)NN)[C@]1(C)CC[C@H]3c4ccc(O)cc4CC[C@]3(C)[C@@H]1C2</smiles>

50a $\mathrm{R}=\mathrm{NH}_{2}$

$50 \mathrm{~b} \mathrm{R}=\mathrm{OH}$

Scheme 13. Synthesis of compounds $46 a-c, 48 a-c$ and $50 a, b$.

\section{Synthesis of Steroidal Derivatives Containing Heterocyclic Side-chains}

In 2014, a series of D-ring substituted pyrazolinyl pregnenolone (54) and pyrazolyl pregnenolone (56) derivatives were synthesized and screened for their 5?-reductase inhibitory activity by Banday et al. ${ }^{38}$ To a solution of pregnenolone $\mathbf{5 1}$ in ethanol was added a solution of $\mathrm{KOH}$. Then aldehyde $\mathbf{5 2}$ was added to the 
reaction mixture to get the corresponding benzylidene derivative $\mathbf{5 3}$. The condensation product $\mathbf{5 3}$ was refluxed in acetic acid in the presence of hydrazine to yield the desired $N$-acetylpyrazolines (Scheme 14).
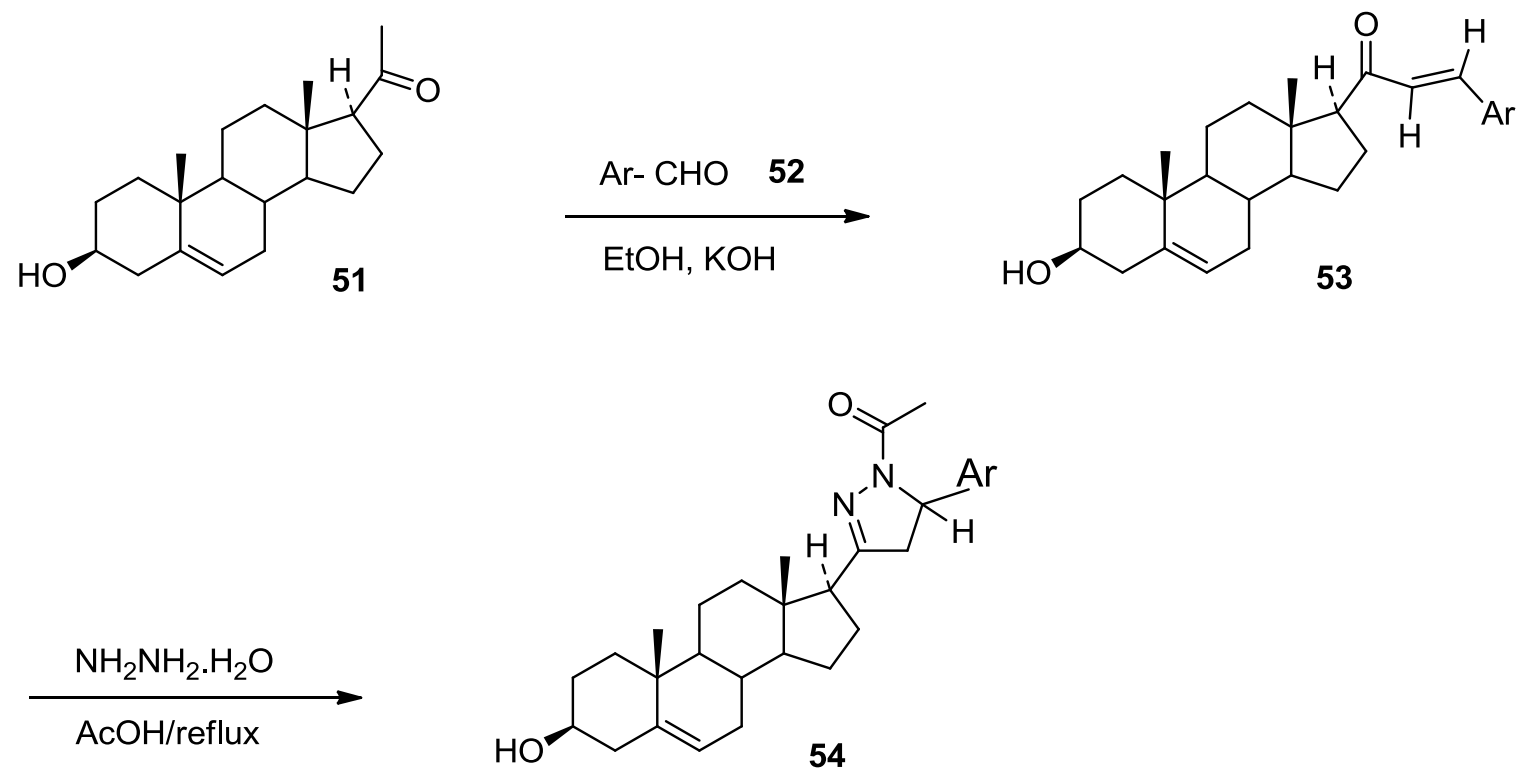

Scheme 14. Synthesis of D-ring substituted pyrazolinyl-pregnenolones.

All the pyrazolyl pregnenolone derivatives were prepared by known literature methods. ${ }^{39}$ The route described by Ivany et al. ${ }^{39}$ involves the cyclization of 30-hydroxy-21-hydroxymethylidenepregn-5-en-20-one $55^{40}$ with phenylhydrazine or its $p$-substituted derivatives (Scheme 15). All the compounds exhibited promising inhibitory activity especially against type I human steroid-5?-reductase.

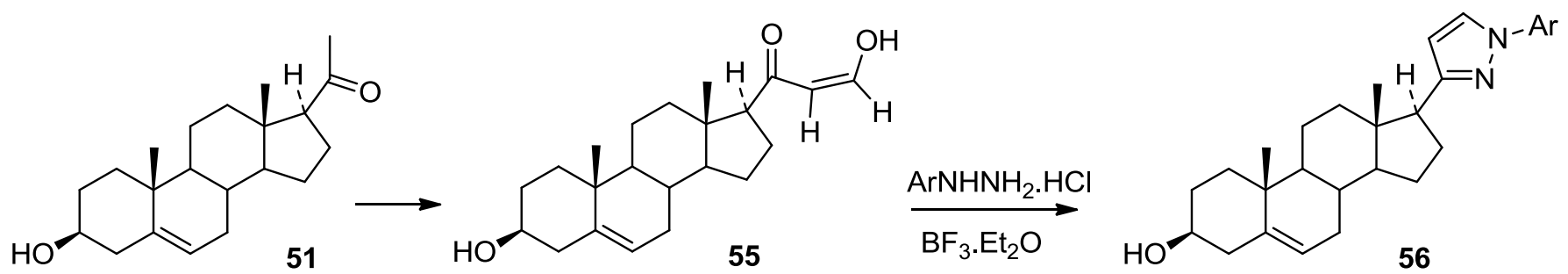

Scheme 15. Synthesis of D-ring substituted pyrazolyl-pregnenolones.

Cui et al. $^{41}$ synthesized a series of dehydroepiandrosterone-17-hydrazone and estrone-17-hydrazone derivatives possessing various aromatic heterocyclic structures at C-17 of their steroidal nucleus. Scheme 16 outlines the synthetic procedures of compounds 58-66. First, the dehydroepiandrosterone was converted into the corresponding dehydroepiandrosterone-17-hydrazone $\mathbf{5 7}$ via reaction with hydrazine hydrate in anhydrous ethanol. After crystallization, reaction of the pure steroidal hydrazone with aromatic aldehydes gave steroidal hydrazone derivatives 58-66.

To determine the effect of the A-ring structure in the steroidal nucleus on the cytotoxicity, they also synthesized compounds 69-73 (Scheme 17). Compounds 69-73 were prepared similarly as the procedures for the synthesis of compounds 58-66. 


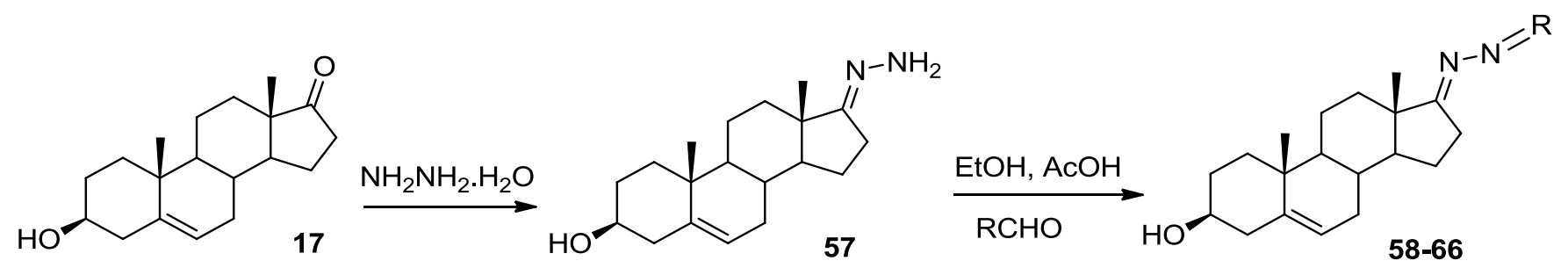<smiles>[R]=Cc1ccccc1</smiles>

63<smiles>N#Cc1cccnc1</smiles>

59<smiles></smiles>

60<smiles>[Mg]=Cc1ccc2ccccc2c1</smiles>

61<smiles>COc1ccc2cc(C=[V])ccc2c1</smiles>

62<smiles>CC(C)(F)Cc1c[nH]c2ccccc12</smiles><smiles>CC(C)=C(C)C</smiles>

66

Scheme 16. Synthesis of compounds 58-66.<smiles>[R]=C=Cc1ccc2ncccc2c1</smiles>

Scheme 17. Synthesis of compounds 69-73.

In 2015, a series of new steroidal heterocyclic compounds with significant anti-tumor and antioxidant activities was successfully synthesized by Abad et al. ${ }^{42}$ All the compounds (Scheme 18) were prepared by refluxing compounds 74e-76e with o-aminothiophenol/ o-aminophenol/ o-phenylenediamine in DMSO. Their anti-tumor activity in vitro was evaluated against Hep3B (human hepatocellular carcinoma), MCF7 (human breast adenocarcinoma), HeLa (human cervical carcinoma) cancer cell lines and on normal PBMCs (peripheral blood mononuclear cells). The results demonstrated that most of the synthesized derivatives showed significant anti-tumor activity; however compounds 78, 79, 81, 82 and 85 exhibited excellent activity with IC50 $<19$ ? $\mathrm{M}$ against all the cancer cell lines. In addition, compounds 83-85 were found to be good antioxidants. Nonenzymatic degradation of DNA has also been investigated. The application of compounds 79 as DNA gene 


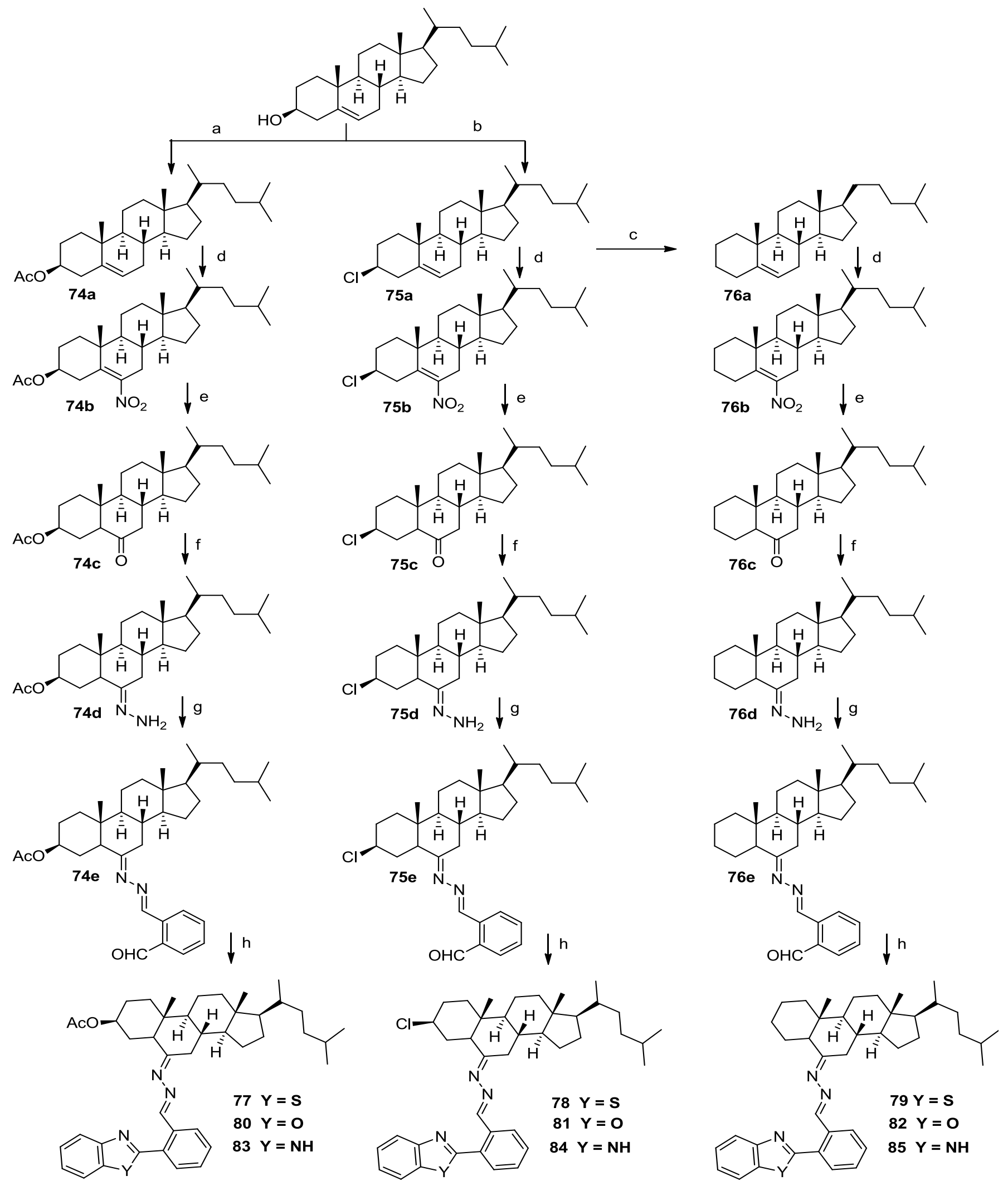

Reagents : a- pyridine; b- $\mathrm{SOCl}_{2}$; c- $\mathrm{Na}$, amyl alcohol; d- $\mathrm{HNO}_{3}$; e- acetic acid, $\mathrm{Zn}$ dust; f- $\mathrm{NH}_{2} \mathrm{NH}_{2} \cdot \mathrm{H}_{2} \mathrm{O}, \mathrm{CH}_{3} \mathrm{COOH}$, ethanol, reflux; g- ethanol, reflux; h- DMSO.

Scheme 18. Synthetic pathways for the formation of steroidal compounds 77-85. 
transporter was evaluated by DNA condensation and ascertained by employing TEM and AFM, which illustrated that the compound $\mathbf{7 9}$ induces the condensation of CT-DNA. Lipinski's 'Rule of Five' analysis predicted good oral absorption of the synthesized compounds. Moreover, the acetylcholinesterase (AChE) inhibitor activities of the steroidal derivatives were also evaluated using Ellman's method. From the results obtained they deduced that compound 77, $\mathbf{8 0}$ and $\mathbf{8 3}$ exhibited significant inhibition on AChE among all the synthesized compounds.

Elmegeed et al. ${ }^{43}$ synthesized new hetero-steroids with promising anticancer effects. The reaction of compound 86 with 4-amino-2-thiouracil 87 in ethanolic solution containing acetic acid afforded the corresponding thioxopyrimidinyl androstane derivative $\mathbf{8 8}$ in $75 \%$ yield. Compound $\mathbf{8 8}$ reacted with hydrazine hydrate in boiling ethanol to give the hydrazinyloxopyrimidinyl androstane derivative 89 in $58 \%$ yield. Treatment of compound $\mathbf{8 9}$ with glacial acetic acid gave the triazolopyrimidinyl androstane derivative $\mathbf{9 0}$ in $64 \%$ yield (Scheme 19$)$.

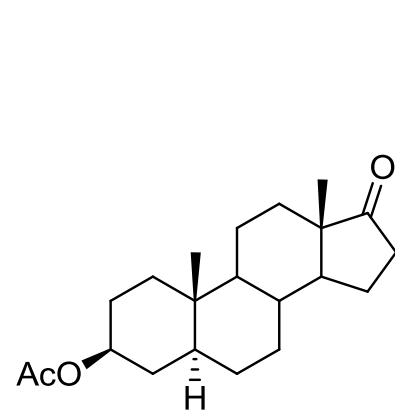

86

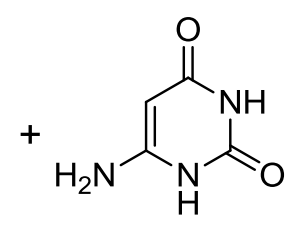

87

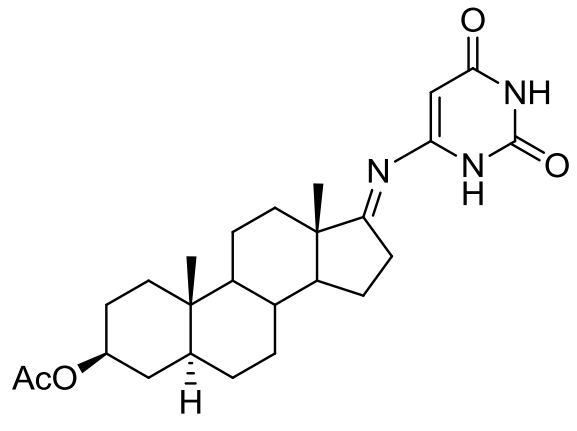

88<smiles>CC(=O)O[C@H]1CC[C@@]2(C)C3CC[C@]4(C)C(=Nc5cc(=O)[nH]c(NN)n5)CCC4C3CC[C@H]2C[C@H](OC(C)=O)C1</smiles>

Scheme 19. Synthesis of compounds 88,89 and 90.

Reaction of compound $91^{30}$ with compound 89 in ethanol gave the corresponding hydroxypyridazinylpyrimidinyl androstane derivative $\mathbf{9 2}$. The structure of compound $\mathbf{9 2}$ was confirmed based on the analytical and spectral data.

The reaction of compound $\mathbf{8 9}$ with curcumin $\mathbf{9 3}$ in glacial acetic acid containing sodium acetate afforded pyrazolo-curcumin-pyrimidinyl androstane derivative 94 in 75\% yield (Scheme 19). Compound 88, 90, 92, 94, showed significant cytotoxic effect on breast cancer cells. This study clarified that the compounds 88, 90, 92, $\mathbf{9 4}$ are the most promising as pro-apoptotic factors. Compounds $\mathbf{8 8}, \mathbf{9 4}$, act through the downregulation of CCND1, survivin, BCL-2 and CDC2 gene expression, while compounds $\mathbf{9 0}$ and $\mathbf{9 2}$ activate the P53/P21 pathway, resulting in tumor suppression and increased apoptosis. 


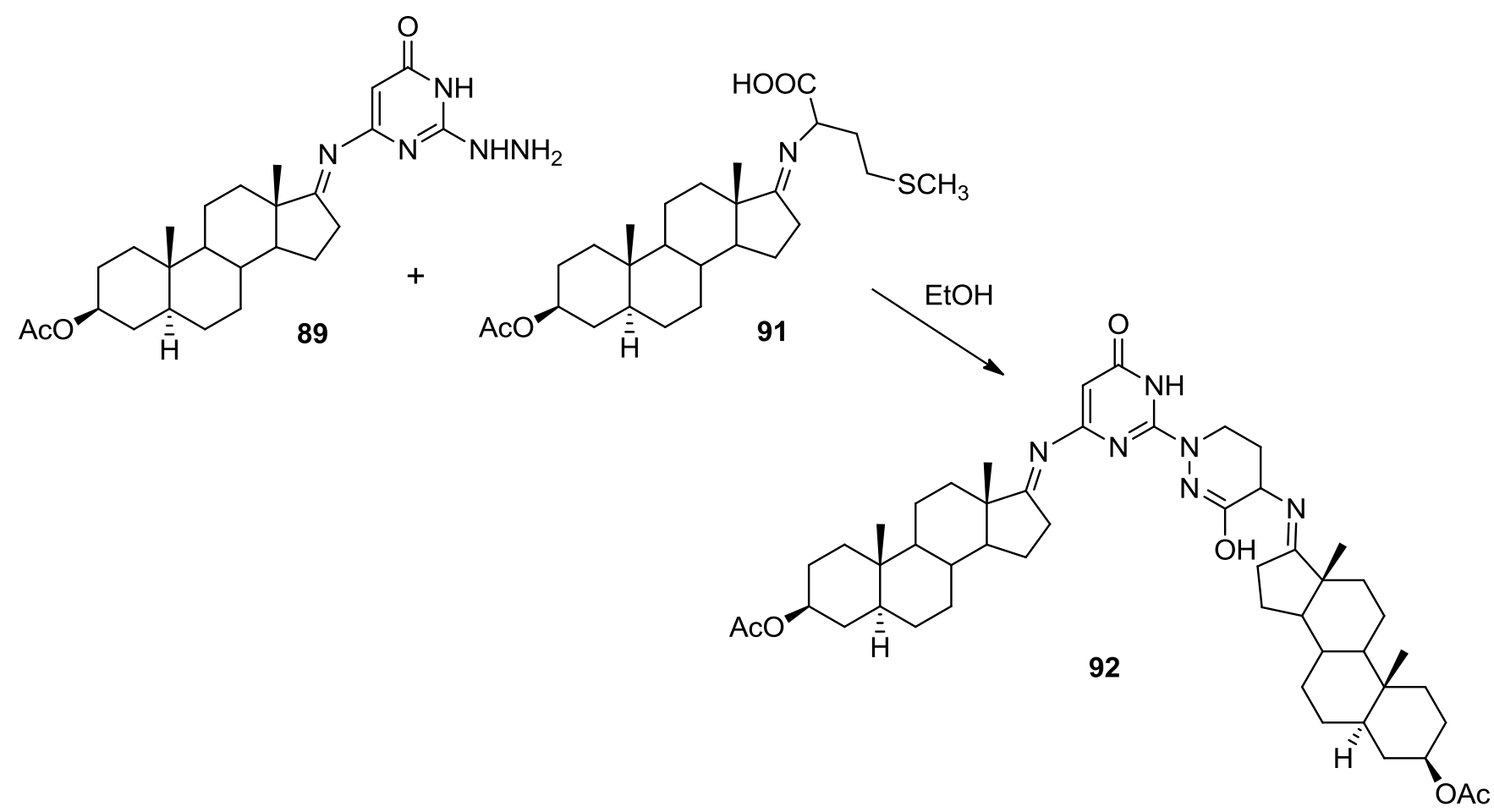
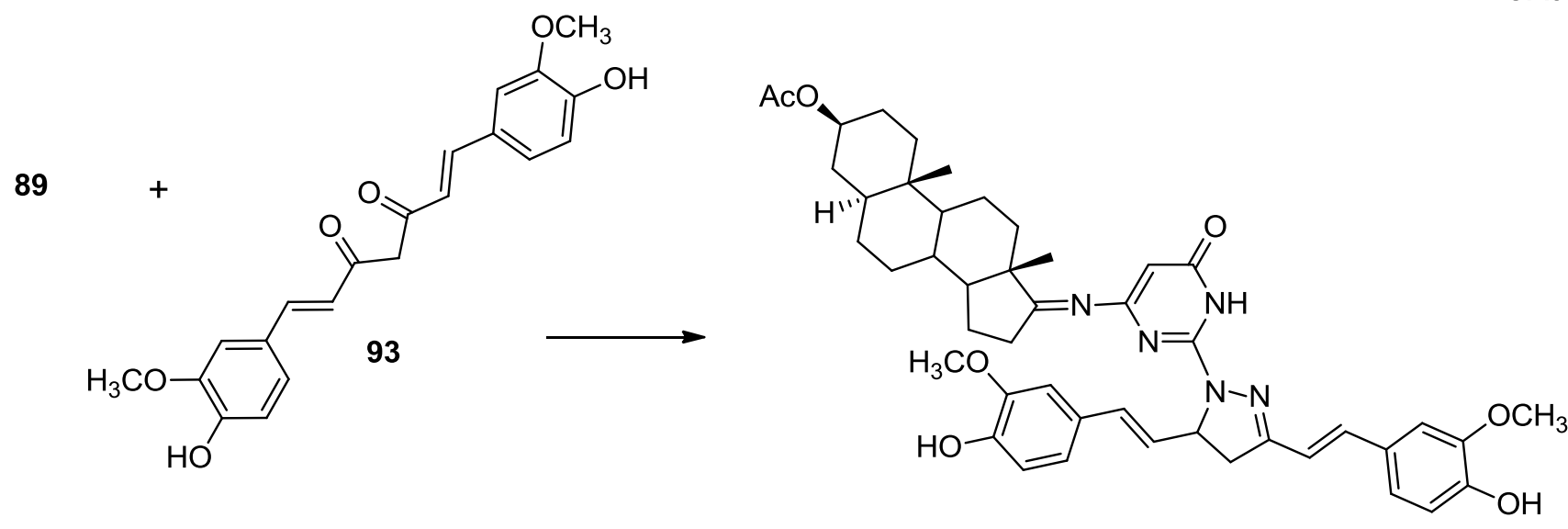

94

Scheme 20. Synthesis of compounds 92 and 94.

In 2016, Vitellozzi et al. $^{44}$ prepared a range of novel steroid analogues bearing a C-17 side-chain containing a 20R-hydroxyl group and a variety of heterocyclic substituents by organometallic additions to 3-methoxypregnenolone. This methodology was extended, by use of the Achmatowicz rearrangement and ring-closing metathesis approaches, to prepare pyrandione and $\delta$-lactone steroidal analogues reminiscent of the withanolide natural products. The addition of simple lithiated heterocycles to the C-20 ketone of steroid 95 were studied first. Thus, 3ß-methoxypregnenolone 95 was added to a solution of 2-lithiothiazole, and a chromatographically inseparable mixture of adducts $\mathbf{9 6 R}$ and $\mathbf{9 6 S}$ (84\%, 9:1) was obtained; however, recrystallisation of the mixture from methanol gave the required $R$-diastereomeric adduct $\mathbf{9 6} R$ in $48 \%$ isolated yield. The addition of other lithiated five-membered heterocycles onto ketone 95 was also investigated. Using thiophene, furan and TBS-protected furfurol, lithiation was aided by the addition of TMEDA, although the isolated yields of adducts 97-99 were depressed by the ease with which the products, particularly 97, underwent dehydration. Nevertheless, the reactions proceeded with complete diastereoselectivity, giving 97R-99R with no sign of the corresponding $S$-isomers. They next examined the addition of lithiated 
benzothiophene, benzofuran and $N$-methylindole (Scheme 21); organometallic addition of such reagents to 20-ketosteroids was not previously reported. All additions proceeded diastereoselectively, although the yields of the adducts were modest $(101 R, 47 \% ; 102 R, 56 \%)$ or low $(103 R, 12 \%)$. In each of these examples, $n$ butyllithium was used for the metallation reactions.

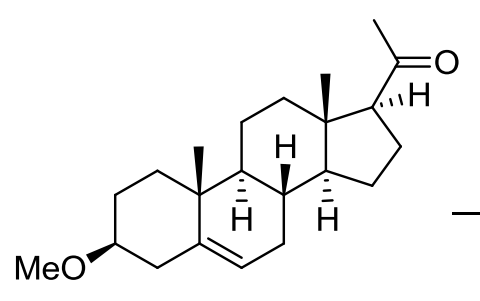

95

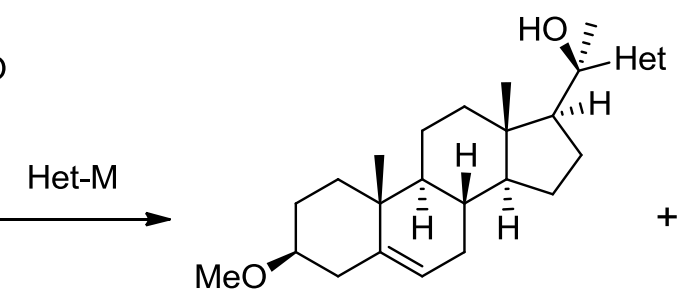

96R-103R

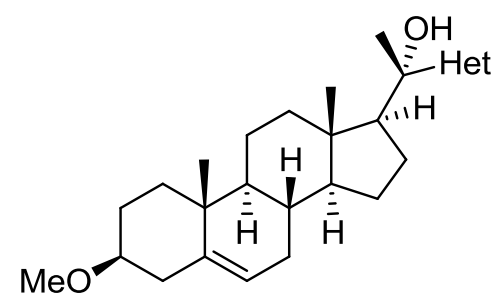

96S-103S

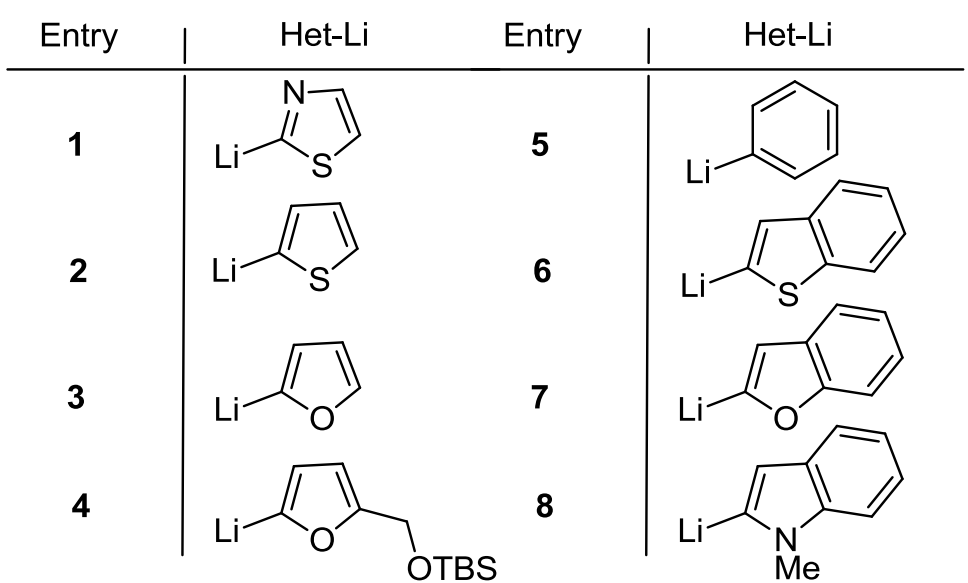

\begin{tabular}{c|c} 
Product & yield (\%) \\
\hline 96 from entry 1 & $84 ; \mathrm{R} / \mathrm{S}: 9 / 1$ \\
97 from entry 2 & $51 ; \mathrm{R} / \mathrm{S}: 98 / 2$ \\
98 from entry 3 & $84 ; \mathrm{R} / \mathrm{S}: 98 / 2$ \\
99 from entry 4 & $75 ; \mathrm{R} / \mathrm{S}: 98 / 2$ \\
100 from entry 5 & $68 ; \mathrm{R} / \mathrm{S}: 9 / 1$ \\
101 from entry 6 & $47 ; \mathrm{R} / \mathrm{S}: 98 / 2$ \\
102 from entry 7 & $56 ; \mathrm{R} / \mathrm{S}: 98 / 2$ \\
$\mathbf{1 0 3}$ from entry 8 & $12 ; \mathrm{R} / \mathrm{S}: 98 / 2$
\end{tabular}

Scheme 21. Organometallic additions to ketone 95.

The authors then explored routes to systems containing a pyrandione or lactone ring in the side-chain to mimic the withanolide (and bufadienolide) natural products. The pyrandione analogue 105 was readily obtained from furan $\mathbf{9 8 R}$ using the Achmatowicz rearrangement ${ }^{45}$ in the key step (Scheme 22). This sequence, originally developed by Kametani et al. $^{46}$ on a closely related system, proceeded efficiently using $N$ bromosuccinimide for the furan ring elaboration, and tetrapropylammonium perruthenate (TPAP)/ $N$ methylmorpholine $\mathrm{N}$-oxide for the oxidation of the lactol 104 to lactone 105.

Following recent research on the use of ring-closing metathesis (MCR) for $\delta$-lactone formation, ${ }^{47} 3$ methoxypregnenolone 95 was treated with allylmagnesium bromide to generate exclusively the 20S-alcohol 106 in 72\% yield (Scheme 23). Subsequent esterification of the sterically hindered tertiary alcohol in 106 with acryloyl chloride afforded ester 107 in 33\% yield. The use of second-generation Hoveyda-Grubbs catalyst then gave the desired $\alpha, \beta$-unsaturated lactone 108 in near quantitative yield. The organometallic addition to generate alcohol 106 occurred with complete Felkin-Anh control. Finally, the authors wanted to investigate whether similar reaction conditions could be applied to the synthesis of the $\alpha, \beta$-dimethyl- $\alpha, \beta$-unsaturated $C$ 20- $\delta$-lactone 111, that is, possessing a substituted lactone moiety typical of withanolide A. Thus, addition of 2 methylallylmagnesium chloride to ketone 95 gave the $\beta$-alcohol 109 in 75\% yield (Scheme 23). Diene 110 was isolated in $12 \%$ unoptimised yield along with recovered starting material. Treatment with the secondgeneration Hoveyda-Grubbs catalyst gave dimethyl- $\alpha, \beta$-unsaturated lactone 111 in $24 \%$ yield. $^{44}$ 

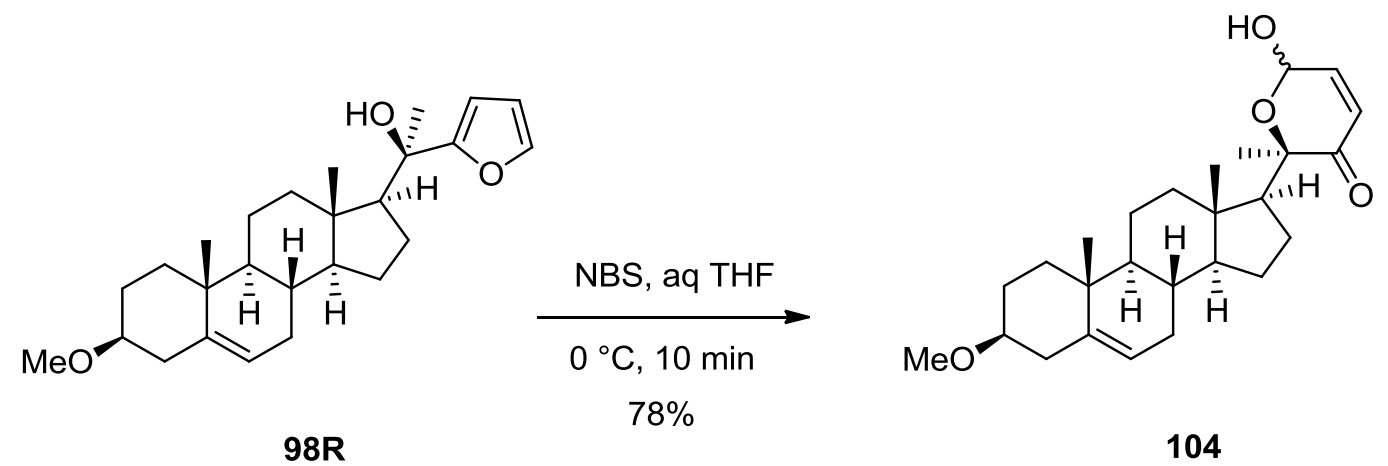

98R

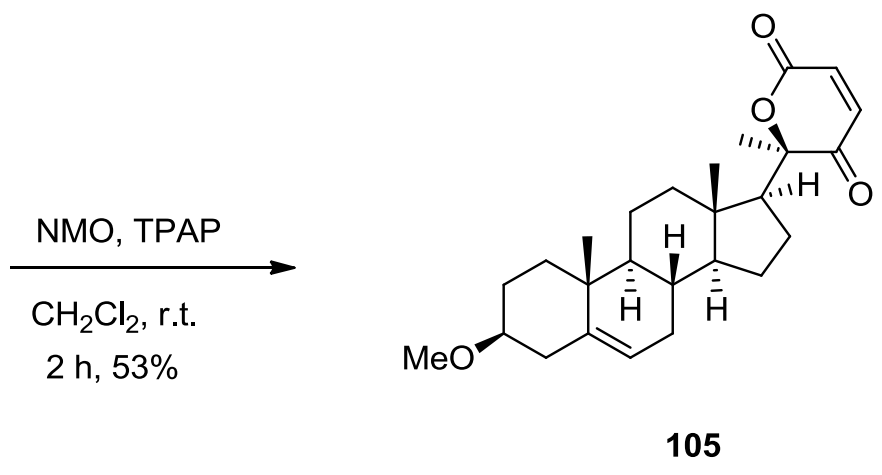

Scheme 22. Preparation of the pyran lactone 105.<smiles>CO[C@H]1CC[C@@]2(C)C(=CC[C@H]3[C@@H]2CC[C@]2(C)[C@@H](C(C)=O)CC[C@H]32)C1</smiles>

95

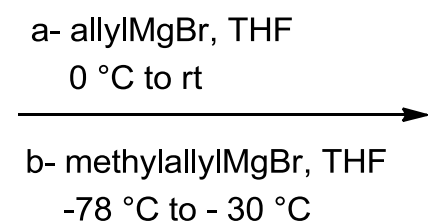

$-78{ }^{\circ} \mathrm{C}$ to $-30^{\circ} \mathrm{C}$<smiles>[R]C(=C)C[C@](C)(OC(=O)C([R])=C)[C@H]1CC[C@H]2[C@@H]3CC=C4C[C@@H](OC)CC[C@]4(C)[C@H]3CC[C@@]21C</smiles>
$a: R=H, 107,33 \%$
$b: R=M e, 110,12 \%$

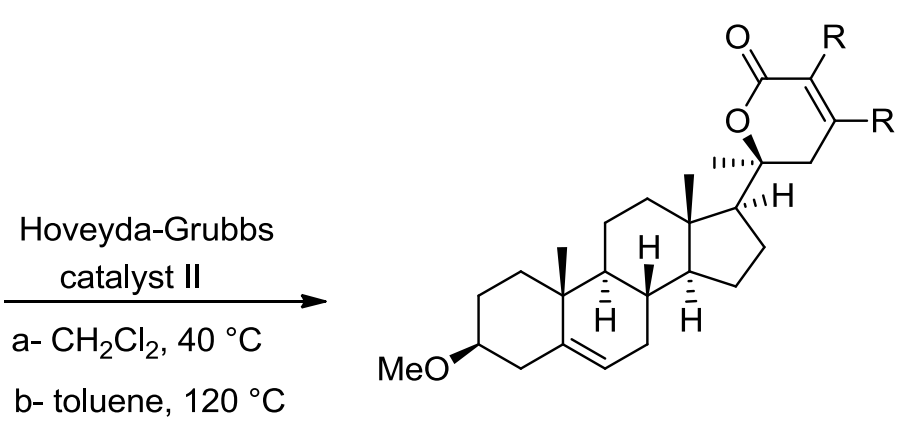

a $: \mathrm{R}=\mathrm{H}, 106,72 \%$

b : $R=M e, 109,75 \%$

$a: R=H, 108,98 \%$
$b: R=M e, 111,24 \%$

Scheme 23. Synthesis of the dihydropyrones 108,111 by RCM reactions 
In 2018, polyhydroxy steroids bearing the $3 \beta, 5 \alpha, 6 \beta$-trihydroxy pattern were synthesized by Mohammed Kolo et al. $^{48}$ from different heterocyclic-substituted unsaturated steroids by a simple and easy method with high yields. $3 \beta$-Acetoxyandrost-5-en-17-one 18 was synthesized from the acylation reaction of DHEA with acetic anhydride in order to protect the hydroxyl group at C-3 from given a side reaction. 3 $\beta$-Acetoxy-17chloro-16- formylandrosta-5,16-diene 112 was synthesized with high efficiency by the Vilsmeier-Haack reaction of compound 18. 3ß-Acetoxy-17-(1H-benzimidazol-1-yl)-16-formylandrosta-5,16-diene 114 was obtained from the reaction of compound $\mathbf{1 1 2}$ with benzimidazole in basic medium. The formyl group on compound 114 was reduced to the corresponding 3 3 -acetoxy-17-(1H-benzimidazol-1-yl)-16(hydroxymethyl)androsta-5,16-diene 156. 17-(1H-Benzimidazol-1-yl)-3 $\beta, 5 \alpha, 6 \beta$-trihydroxy-16-(hydroxymethyl)16-androstene 116 was synthesized with good efficiency from the reaction of compound 115 with m-CPBA and methanolic $\mathrm{KOH}$ (Scheme 24).

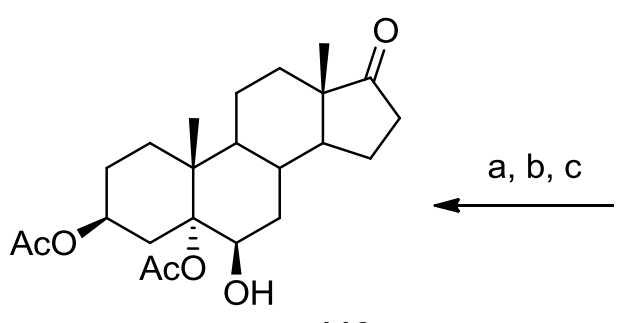

112

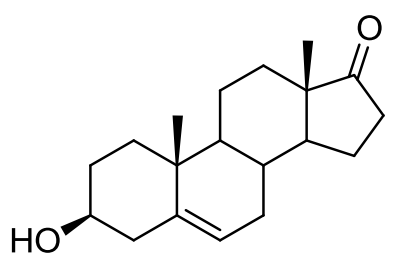

DHEA

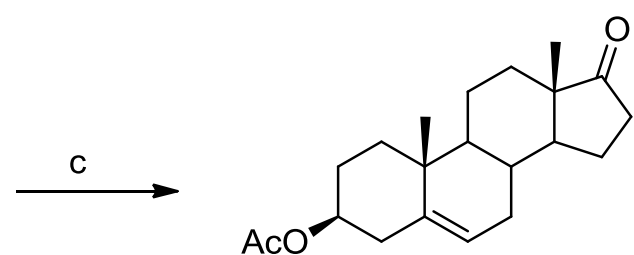

18

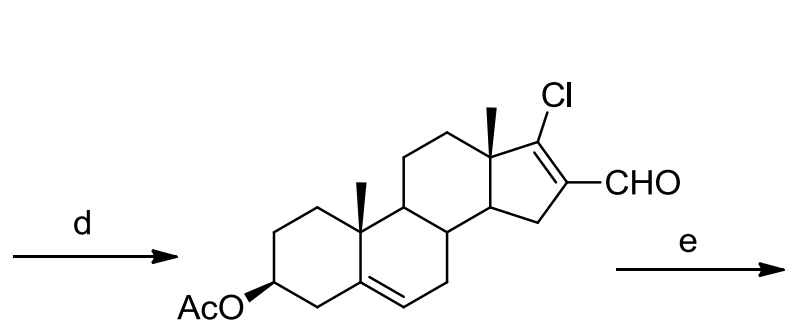

113

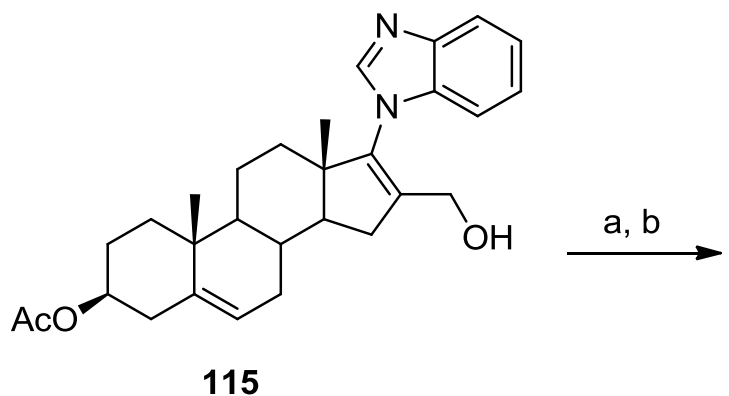<smiles>CC1(C)O[C@H]2CC[C@@]3(C)C(=CCC4C3CC[C@@]3(C)C(n5cnc6ccccc65)=C(C=O)CC43)C[C@@H]21</smiles>

114<smiles>C[C@]12CCC3C(C[C@H](O)[C@@]4(O)C[C@@H](O)CC[C@]34C)C1CC(CO)=C2n1cnc2ccccc21</smiles>

Reagents and conditions: a- m-chloroperoxybenzoic acid, $25^{\circ} \mathrm{C}, 15 \mathrm{~h}$; b- $5 \%$ methanolic $\mathrm{KOH}, 25^{\circ} \mathrm{C}, 24 \mathrm{~h}$; C- acetic anhydride, pyridine, $25^{\circ} \mathrm{C}, 2 \mathrm{~h}$; d- $\mathrm{POCl}_{3}$, dimethylformamide, $80^{\circ} \mathrm{C}$, $5 \mathrm{~h}$; benzimidazole, $\mathrm{K}_{2} \mathrm{CO}_{3}, 80{ }^{\circ} \mathrm{C}, 2 \mathrm{~h}$; e- $\mathrm{NaBH}_{4}, 25^{\circ} \mathrm{C}, 16 \mathrm{~h}, \mathrm{DHEA}$, trans-dehydroandrosterone.

Scheme 24. Synthesis of 17-benzimidazolyl-16-(hydroxymethyl)androst-16-ene-3,5,6-triol.

16E-Arylidene steroidal derivatives 117-119 were synthesized from the base-catalyzed condensation reaction of DHEA with the heteroaromatic aldehydes such as thiophene-2-carboxaldehyde, thiophene-3carboxaldehyde, and quinoline-2-carboxaldehyde (Scheme 25). In the structure of compounds 117-119, the new exocyclic double bond $\left(\Delta^{16}\right)$ was a consequence of the condensation reaction. Different heteroaryl- 
substituted new trihydroxyandrosterone derivatives 120-122 were synthesized from the reaction of $\alpha, \beta$ unsaturated heterocyclic-substituted steroids 117-119 with $\mathrm{m}$-CPBA in dichloromethane and methanolic $\mathrm{KOH}$. $m$-CPBA converts only the endocyclic double bond of compounds 117-119 to trans-diaxial diol derivatives with both regioselective and stereoselective reaction. In situ reaction, firstly, the endocyclic double bond transforms to epoxides and then resulting in the trans-dihydroxylation by opening the ring with the anti-attack of the hydroxyl nucleophile. DHEA and the compounds $\mathbf{1 1 5}$ and 117-119 were converted into the compounds 116 and $120-122$ by this method.

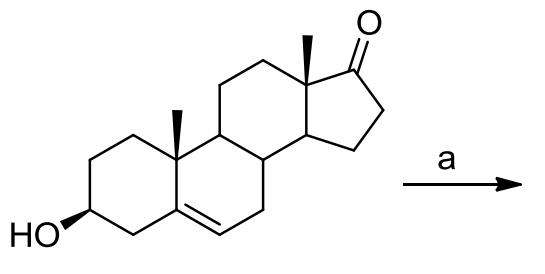

Hetaryl $=\left\langle\prod_{S}\right.$

117-120

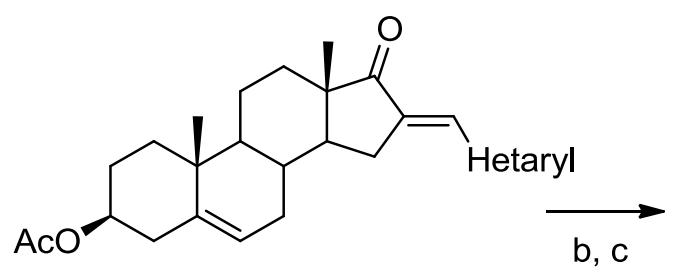

117-119

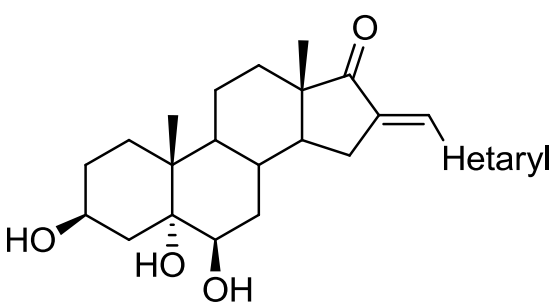

120-122

Reagents and conditions: a- $\mathrm{NaOH}$, requisite aldehyde, $25^{\circ} \mathrm{C}, 3 \mathrm{~h} ; \mathrm{b}-\mathrm{m}$-chloroperoxybenzoic acid, $25^{\circ} \mathrm{C}, 15 \mathrm{~h}$; c- $5 \%$ methanolic $\mathrm{KOH}, 25{ }^{\circ} \mathrm{C}, 24 \mathrm{~h}$.

Scheme 25. Synthesis of 16-(heteroarylmethylene)androstane-17-ones 120-122.

Motyan et al. $^{49}$ developed a microwave-assisted one-pot method for the facile and efficient synthesis of novel steroidal 17-exo-pyrazol-5'-ones from a $\beta$-ketoester precursor with arylhydrazine hydrochlorides. The steroidal $\beta$-ketoester precursor $\mathbf{1 2 6}$, suitable for the attempted heterocyclization reaction with hydrazines, was synthesized from commercially available pregnenolone acetate $\mathbf{1 2 3}$ via a multistep sequence (Scheme 26). First compound 123 was converted to the $17 \beta$-carboxylic acid $\mathbf{1 2 4 b}$ by the bromoform reaction and subsequent acetylation according to well-known literature procedures. ${ }^{50}$ After the activation of $124 \mathrm{~b}$ with $1,1^{\prime}$-carbonyldiimidazole (CDI) as coupling reagent in THF, the magnesium enolate of malonic acid half ester prepared in situ was added. The acylation of magnesium methyl malonate by the preformed imidazole 125 led to the desired bifunctional starting material 126 in good yield (79\%). Analogously, $\beta$-ketoester 126' could be obtained from pregnadienolone acetate 123' through a $\Delta^{5,16}$-carboxylic acid intermediate under identical conditions albeit in disappointing low yield (33\%) which is presumably caused by the decreased propensity of the conjugated carbonyl compound to react with the magnesium enolate. 


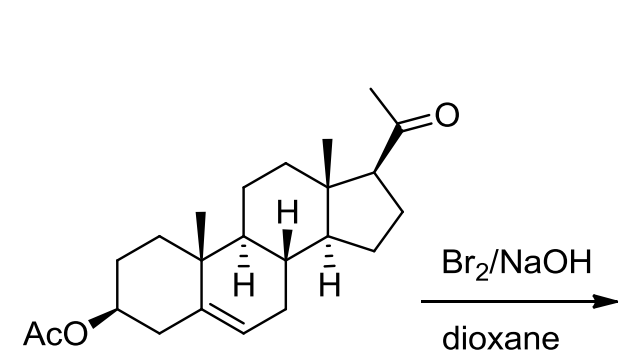

123

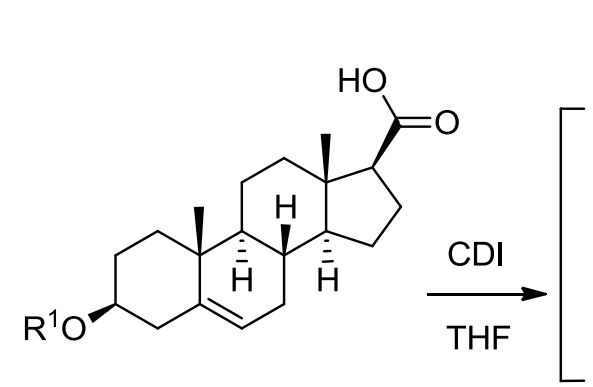

124a $R^{1}=H$

$124 b R^{1}=A c$

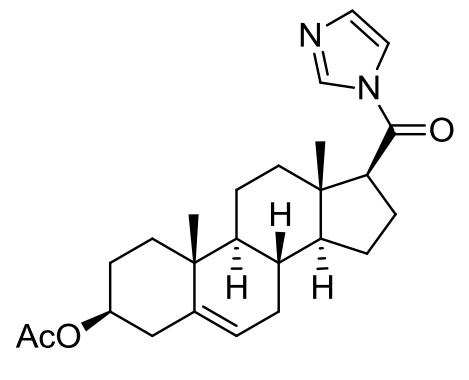

125<smiles>COC(=O)CC(=O)[Te][O]</smiles>

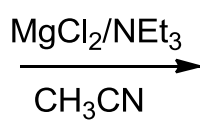<smiles>COc1ccc(OC)cc1</smiles>

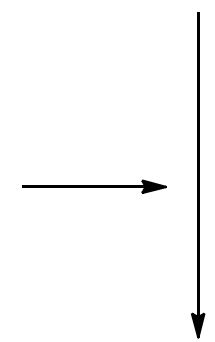

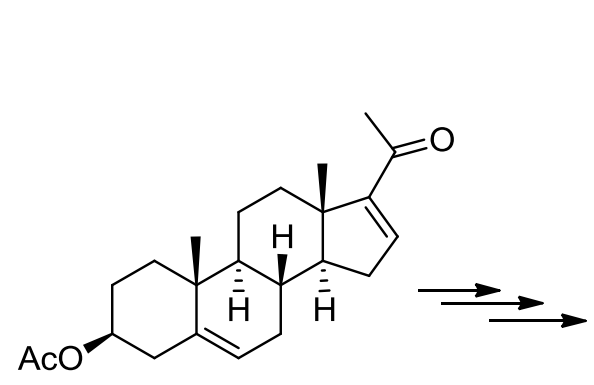

123'

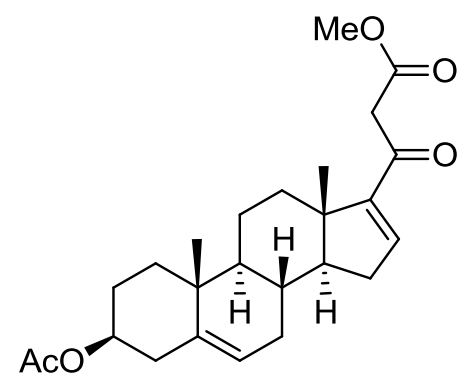

$126^{\prime}$

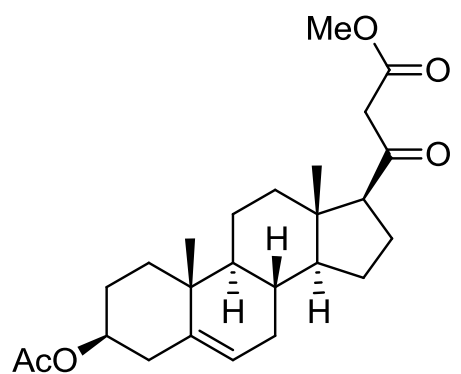

126

Scheme 26. Multistep synthesis of steroidal ?-ketoesters 126 and 126' from pregnenolone acetate 123 and pregnadienolone acetate 123'

The ring-closure reactions of $\mathbf{1 2 6}$ with unsubstituted and monosubstituted hydrazines as binucleophilic reagents were investigated next. First, compound 126 was reacted with hydrazine hydrate 127a in refluxing ethanol containing a catalytic amount of $\mathrm{AcOH}$ (Scheme 27). Full conversion of 126 within $4 \mathrm{~h}$ reaction time afforded a fairly polar product insoluble or only slightly soluble in all commonly used NMR solvents. However, a subsequent derivatization with acetic anhydride in pyridine to afford 130, allowed its structure verification indirectly. This derivatization did not only improve the solubility of the compound, but also eliminated the possibility of prototropic tautomerism through acetylation of both the amino and hydroxy groups present in the heterocyclic ring in 128a. The reaction with phenylhydrazine 127b was completed within $7 \mathrm{~h}$ in refluxing $\mathrm{EtOH}$ in the presence of an acid catalyst. A reduction of the reaction time to $3 \mathrm{~h}$ could be achieved by changing the solvent to $\mathrm{AcOH}$ affording the desired product 128b in high yield (86\%, Scheme 27). On the other hand, the reaction of $\mathbf{1 2 6}$ with methylhydrazine $\mathbf{1 2 7 c}$ required a longer reaction time in refluxing AcOH to furnish the

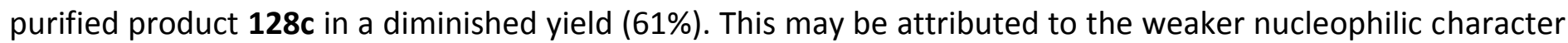
of the external $\mathrm{N}$ compared to the internal one in $127 c^{51}$ in contrast to phenylhydrazine $127 \mathrm{~b}$, making the first condensation step more difficult. The regioselectivity of the reactions with monosubstituted hydrazines is controlled by the higher reactivity of the ketone moiety over the ester towards nucleophiles, and the least 
hindered terminal nitrogen atom of the binucleophiles. Both reactions were repeated in $\mathrm{AcOH}$ under microwave conditions at $120^{\circ} \mathrm{C}$ furnishing products $128 \mathrm{~b}$ and $128 \mathrm{c}$ within a shorter time (20 min and $\left.40 \mathrm{~min}\right)$, however, without substantial improvement in the yields.

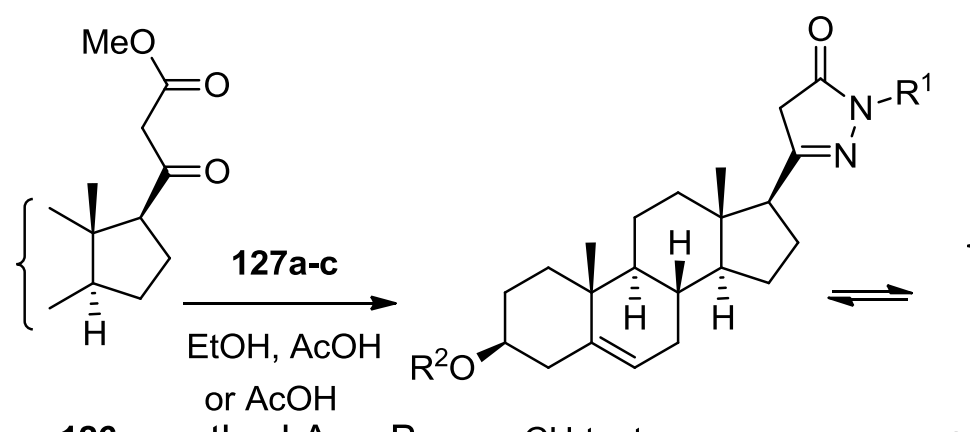

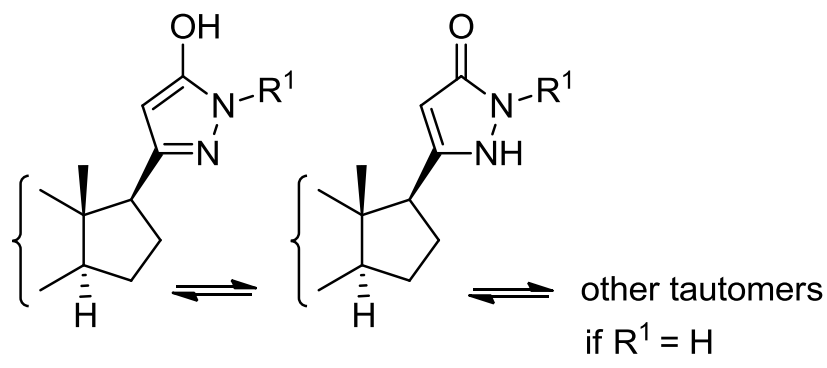
126 method $A$ or $B$ $\mathrm{CH}$-tautomer $\mathrm{OH}$-tautomer $\mathrm{NH}$-tautomer

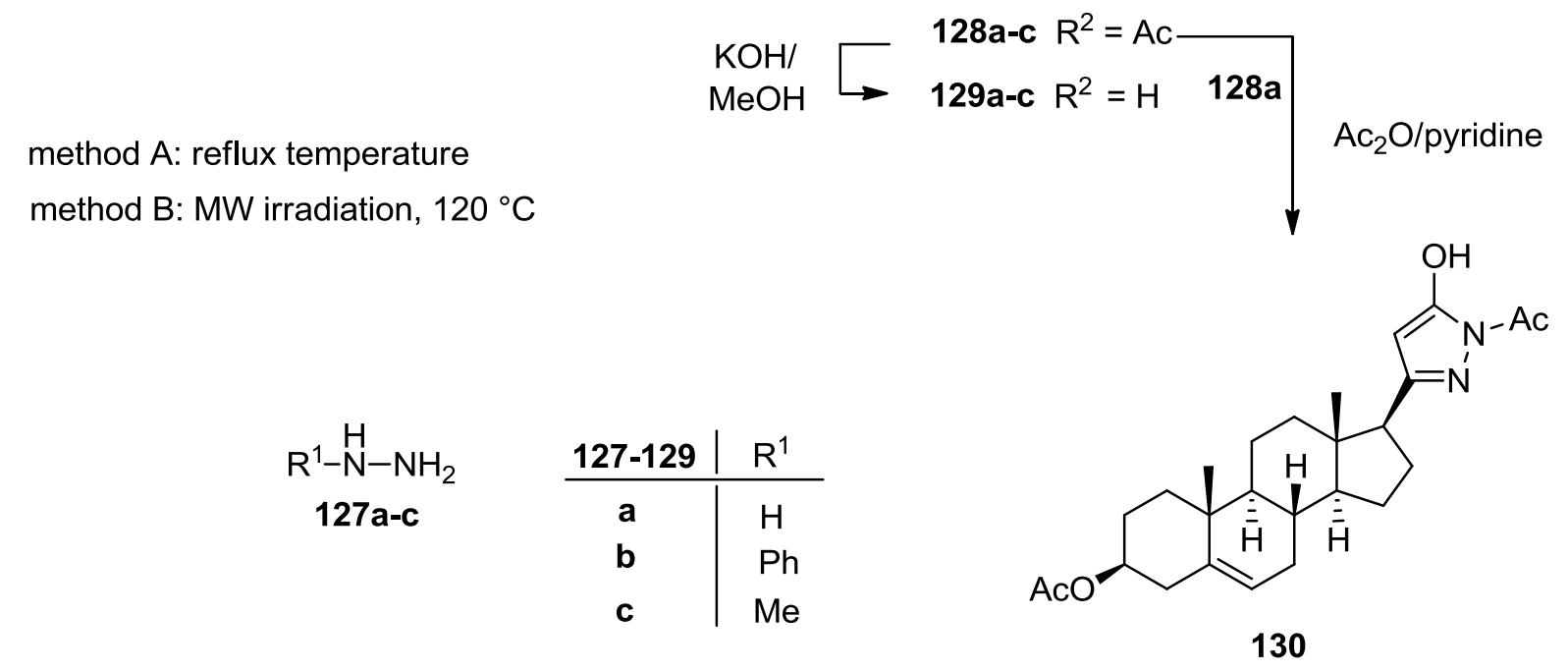

Scheme 27. Cyclization of compound 126 with hydrazine hydrate $127 \mathrm{a}$, phenylhydrazine $\mathbf{1 2 7 b}$ and methylhydrazine $\mathbf{1 2 7 c}$.

After optimizing the conditions for the MW-assisted synthesis of $\mathbf{1 2 8 b}$ from 126 with $\mathbf{1 2 7} \cdot \mathrm{HCl}$, analogous heterocyclization reactions were carried out with different substituted phenylhydrazine hydrochlorides $\mathbf{1 2 7 d -}$ j. All reactions furnished the corresponding 17-exo-heterocycles $129 \mathbf{d}-\mathbf{j}$ in good to excellent yields (83-92\%, Scheme 28). Some of these compounds (128h, 129f, 129i and 129j) exerted considerable antiproliferative activity with promising cancer selectivity on a panel of human breast cancer cell lines. This indicates that the pyrazolone heterocyclic ring at the $17 \beta$ position is a promising scaffold for the design of anticancer agents of the $\Delta^{5}$-androstene series. 


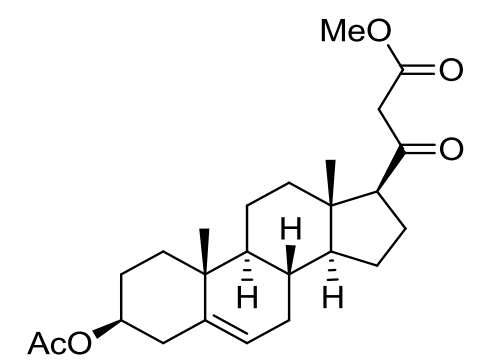

126

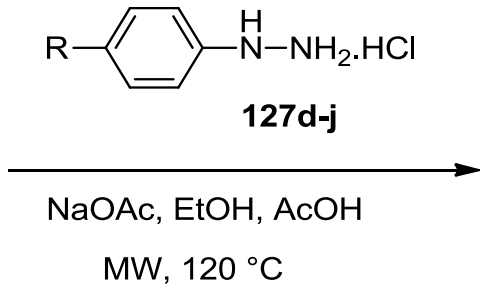

\begin{tabular}{c|c}
$\mathbf{1 2 7}$ & $\mathrm{R}$ \\
\cline { 2 - 2 } $\mathbf{d}$ & $\mathrm{Me}$ \\
$\mathbf{e}$ & $\mathrm{iPr}$ \\
$\mathbf{f}$ & $\mathrm{tBu}$ \\
$\mathbf{g}$ & $\mathrm{OMe}$ \\
$\mathbf{h}$ & $\mathrm{F}$ \\
$\mathbf{i}$ & $\mathrm{Cl}$ \\
$\mathbf{j}$ & $\mathrm{Br}$
\end{tabular}

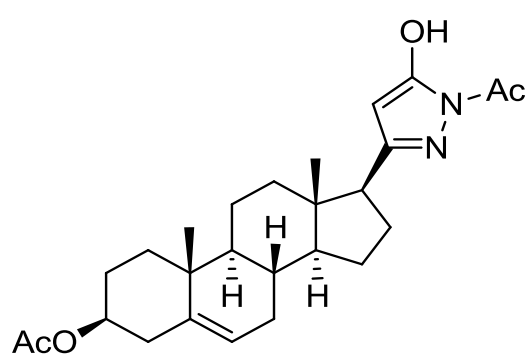

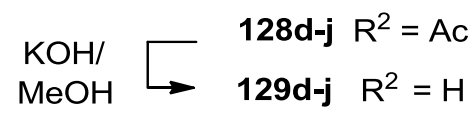

\begin{tabular}{c|c}
$\mathbf{1 2 9}$ & yield (\%) \\
\hline $\mathbf{d}$ & 86 \\
$\mathbf{e}$ & 90 \\
$\mathbf{f}$ & 87 \\
$\mathbf{g}$ & 92 \\
$\mathbf{h}$ & 85 \\
$\mathbf{i}$ & 83 \\
$\mathbf{j}$ & 85
\end{tabular}

Scheme 28. Synthesis of steroidal $N\left(1^{\prime}\right)$-aryl-substituted pyrazol-5'-ones.

Kotovshchikov et al. ${ }^{52}$ developed a regioselective approach to 5-carboxy-1,2,3-triazoles based on the Cucatalyzed synthesis of 5-iodo-1,2,3-triazoles and subsequent Pd-catalyzed carbonylation. To demonstrate the applicability of their protocol for the derivatization of complex natural products, they introduced an azido group to cortexolone 130, an important steroidal hormone (Scheme 29). Azide 131 was subsequently transformed into iodotriazole 132 and the corresponding methyl ester 133, in high yields for both steps (91 and $84 \%$, respectively).

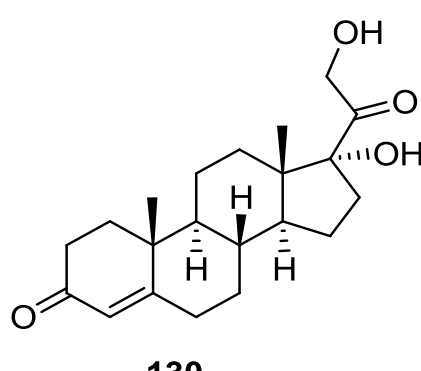

130

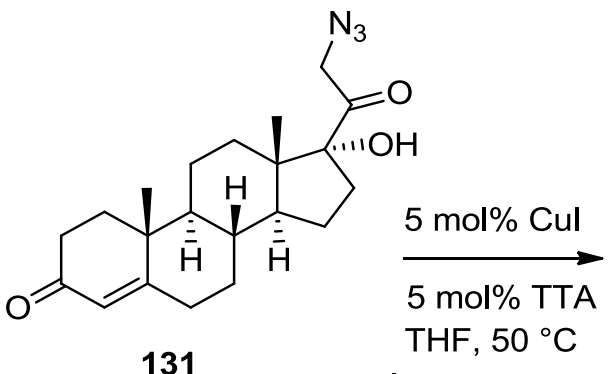

131<smiles>C[C@@]12CCC(=O)C=C1CC[C@@H]1[C@@H]2CC[C@@]2(C)[C@H]1CC[C@]2(C)C(=O)Cn1nnc(CO)c1I</smiles>

$132,91 \%$

$5 \mathrm{~mol} \% \mathrm{Pd}(\mathrm{OAc})_{2}$

$\underset{\mathrm{MeOH}, \mathrm{Et}_{3} \mathrm{~N}}{\mathrm{CO}(1 \mathrm{~atm})}+$<smiles>COCc1c(CO)nnn1CC(=O)[C@]1(O)CC[C@H]2[C@@H]3CCC4=CC(=O)CC[C@]4(C)[C@H]3CC[C@]21C</smiles>

$133,84 \%$

Scheme 29. Modification of cortexolone. 


\section{Synthesis of Steroidal Spiro-heterocycles}

In 2014, Yamansarov et al. $^{53}$ synthesized for the first time steroidal 1,2,4-trioxolanes by ozonolysis of methyl 3(methoxyimino)-5 $\beta$-cholan-24-oate with ketones. As starting compound they used methyl 3-oxo-5 $\beta$-cholan-24oate $\mathbf{1 3 5}$ which was prepared from commercially available lithocholic acid $\mathbf{1 3 4}$ according to standard procedures. The reaction of $\mathbf{1 3 5}$ with a slight excess of $O$-methylhydroxylamine hydrochloride in boiling methanol-pyridine gave $93 \%$ of $O$-methyl ketone oxime $\mathbf{1 3 6}$ which was isolated as a mixture of two isomers at a ratio of $1: 1$ (Scheme 30). Methyl 3-(methoxyimino)-5 $\beta$-cholan-24-oate 136 was ozonolysed in the presence of ketones (cyclohexanone, methyl trifluoromethylketone, phenyl trifluoromethyl ketone) in a mixture of methylene chloride with cyclohexane. Compounds $137-139$ were isolated in $53-82 \%$ yield.

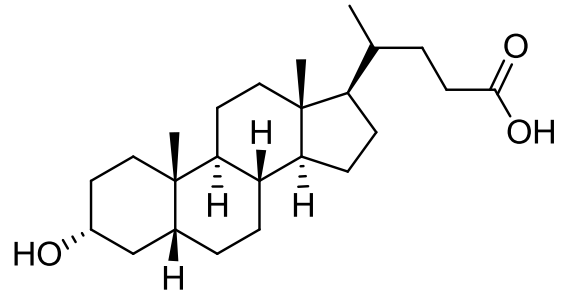

134

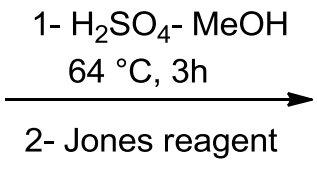

$0{ }^{\circ} \mathrm{C}, 1 \mathrm{~h}$

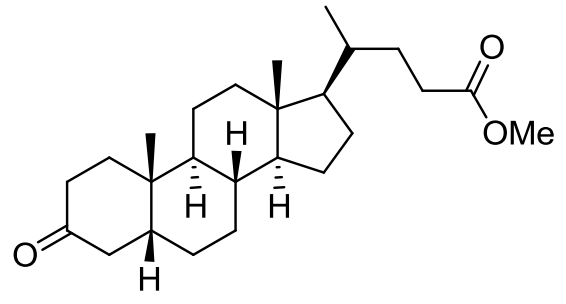

135

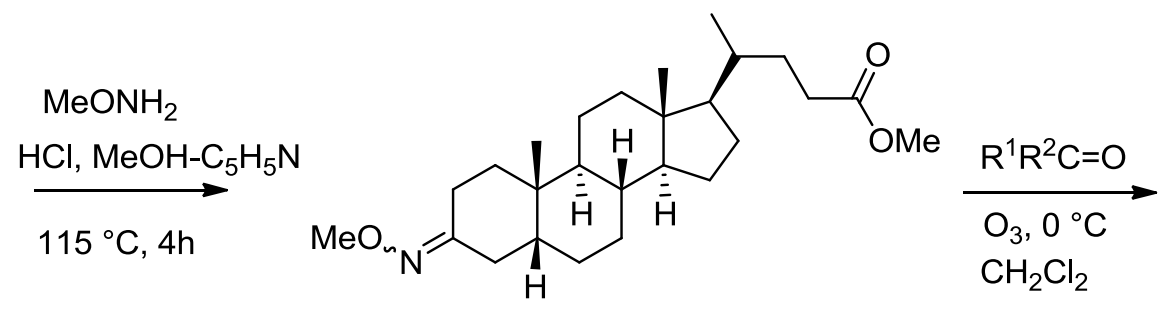

136

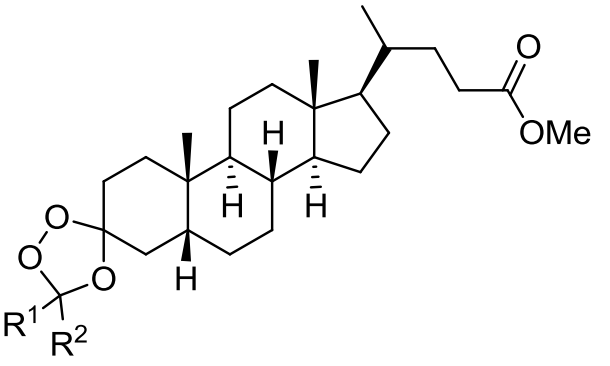

$137 \mathrm{R}^{1}=\mathrm{R}^{2}=\left(\mathrm{CH}_{3}\right)_{5}$
$138 \mathrm{R}^{1}=\mathrm{CF}_{3}, \mathrm{R}^{2}=\mathrm{CH}_{3}$
$139 \mathrm{R}^{1}=\mathrm{CF}_{3}, \mathrm{R}^{2}=\mathrm{Ph}$

Scheme 30. Synthesis of steroidal 1,2,4-trioxolanes.

In 2016, a facile one-pot synthesis of novel steroidal dispiro-indenoquinoxaline pyrrolidines via multicomponent-[3+2]-cycloaddition of azomethine ylides in ionic liquid was described by Gavaskar et al. ${ }^{54}$ They reported a mild and expeditious one-pot sequential four-component synthesis of novel steroidal dispiropyrrolidine heterocycles through 1,3-dipolar cycloaddition of azomethine ylide generated from 1,2phenylenediamine, ninhydrin and sarcosine with various unusual estrone-derived dipolarophiles in the ionic liquid N-(1-acryloyl)-N-(4-cyclopentyl)-piperazinium phosphate synthesized by them ${ }^{55}$ recently (Scheme 31).

Initially, they investigated the one-pot sequential four-component reaction involving ninhydrin 141, 1,2phenylenediamine 142, sarcosine 143 and estrone-derived dipolarophiles 140a-h which proceeded well in the ionic liquid $\mathbf{1 4 4}$ to give a series of novel steroidal dispiroindenoquinoxaline pyrrolidines $145 a-h$ as the only products in good yield (76-85\%). The formation of the hybrid steroidal heterocyclic scaffold 145 involved a multistep sequence. This method of sequential assembly of steroid grafted spiro-pyrrolidines in ionic liquid medium offers several advantages including its simplicity with a one-pot four-component approach, mild 
reaction conditions, easy workup, affording the desired products in good yield from readily and cheaply available starting materials in a single step. This method is general and is applicable for the synthesis of a variety of unusual complex highly substituted pyrrolidines containing steroidal and spiro-indenoquinoxaline moiety of biological significance.<smiles>[R]c1cc(/C=C2/CC3C4CCc5cc(O)ccc5C4CC[C@@]3(C)C2=O)cc([R])c1[R]</smiles>

140a-h<smiles>O=C1c2ccccc2C(=O)C1(O)O</smiles>

141
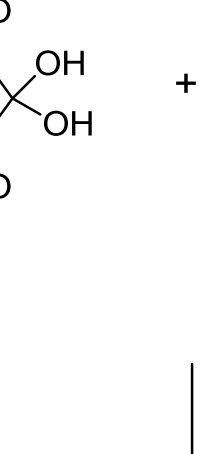<smiles>Nc1ccccc1N</smiles>

$+\quad \mathrm{CH}_{3}-\mathrm{NH}-\mathrm{CH}_{2}-\mathrm{COOH}$

142

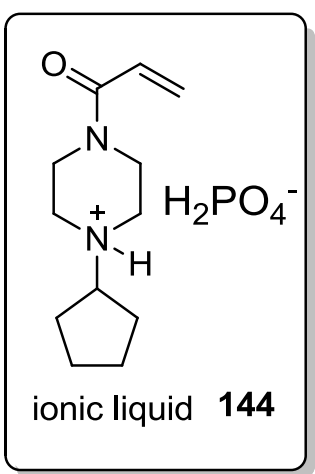

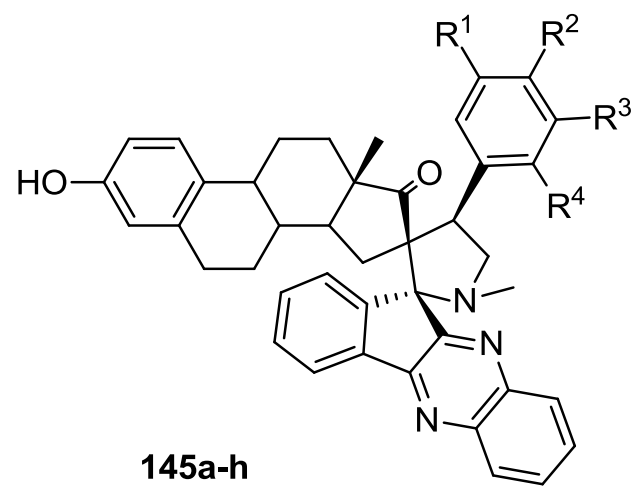

$R^{1} / R^{2} / R^{3} / R^{4}$

$146 \mathrm{a}-\mathrm{h}$

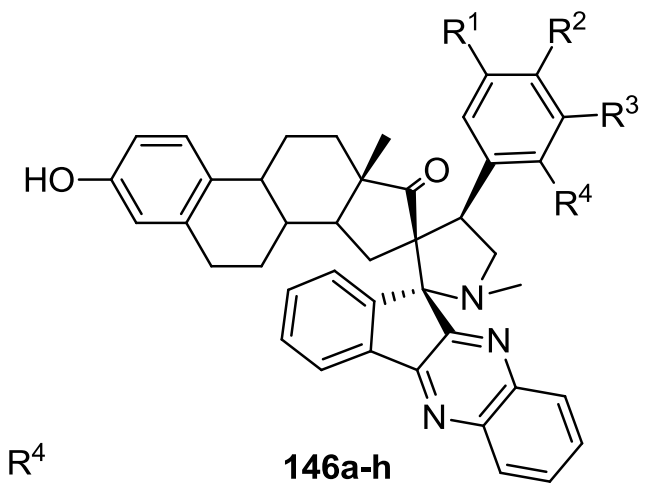

$=\mathrm{H}, \mathrm{Cl}, \mathrm{Me}, \mathrm{OMe}$

Scheme 31. Synthesis of steroidal spiro-indenoquinoxaline-pyrrolidines 145a-h.

In 2018, Yamansarova et al. ${ }^{56}$ reported the synthesis of 1,2,4-trioxolanes of deoxycholic acid by the Griesbaum co-ozonolysis and compared their antimalarial activity with 1,2,4,5-tetraoxanes obtained by acidcatalyzed peroxycondensation. They used deoxycholic acid as an available starting material to synthesize steroidal peroxides. The required ketone 147 was obtained according to the procedure previously described. ${ }^{57}$ The next step included high-yield selective preparation of $O$-methyl oxime $\mathbf{1 4 8}(90 \%)$ as a mixture of syn-/antiisomers in a ratio of 1:1 (Scheme 32). Thus, they introduced the unsaturated $\mathrm{C}=\mathrm{N}$ double bond into the structure of the initial substrate. In the subsequent synthesis intermediate $\mathbf{1 4 8}$ was applied as a mixture of oximes. The Griesbaum co-ozonolysis ${ }^{58}$ of 148 in the presence of fluorinated ketones $\mathrm{CF}_{3} \mathrm{C}(\mathrm{O}) \mathrm{CH}_{3}$ or $\mathrm{CF} \mathrm{C}_{3} \mathrm{C}(\mathrm{O}) \mathrm{Ph}$ gave 1,2,4-trioxolanes 149 and 150 in yields of $50 \%$ and 38\%, respectively. A byproduct of these reactions was the expected lactam 151 isolated in yields of $14 \%$ and 10\%, respectively. Surprisingly, the ozonolysis of 148 
without the presence of ketones gave the lactam 151 as the major reaction product (52\%). It was noted that the Griesbaum co-ozonolysis of 148 in the presence of acetone gave no 1,2,4-trioxolanes, perhaps due to its low dipolarophilicity. The ozonolysis reactions were carried out in cyclohexane- $\mathrm{CH}_{2} \mathrm{Cl}_{2}$ solvent mixture at $0{ }^{\circ} \mathrm{C}$ and the ozonides obtained were isolated as the mixtures of achiral diastereomers. For compound 149, the only major diastereomer 149a was separated from hexane by crystallization of a stereoisomeric mixture and individually characterized. A $\left(3 S, 3^{\prime} R\right)$-configuration was assigned based on X-ray crystallographic analysis.
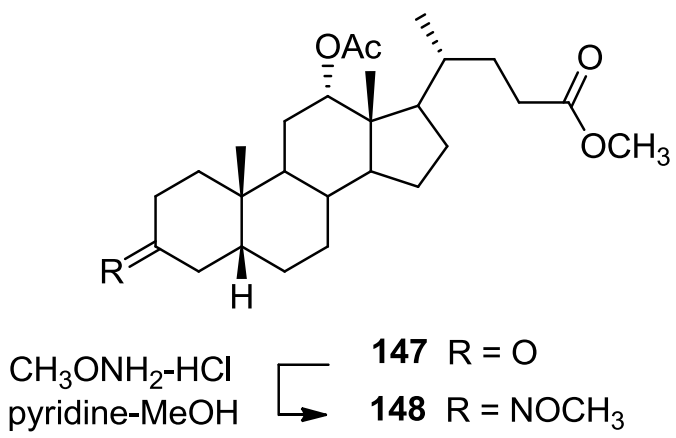

ketone

$\mathrm{O}_{3} / \mathrm{CH}_{2} \mathrm{Cl}_{2}$-cyclohexane

$0{ }^{\circ} \mathrm{C}$

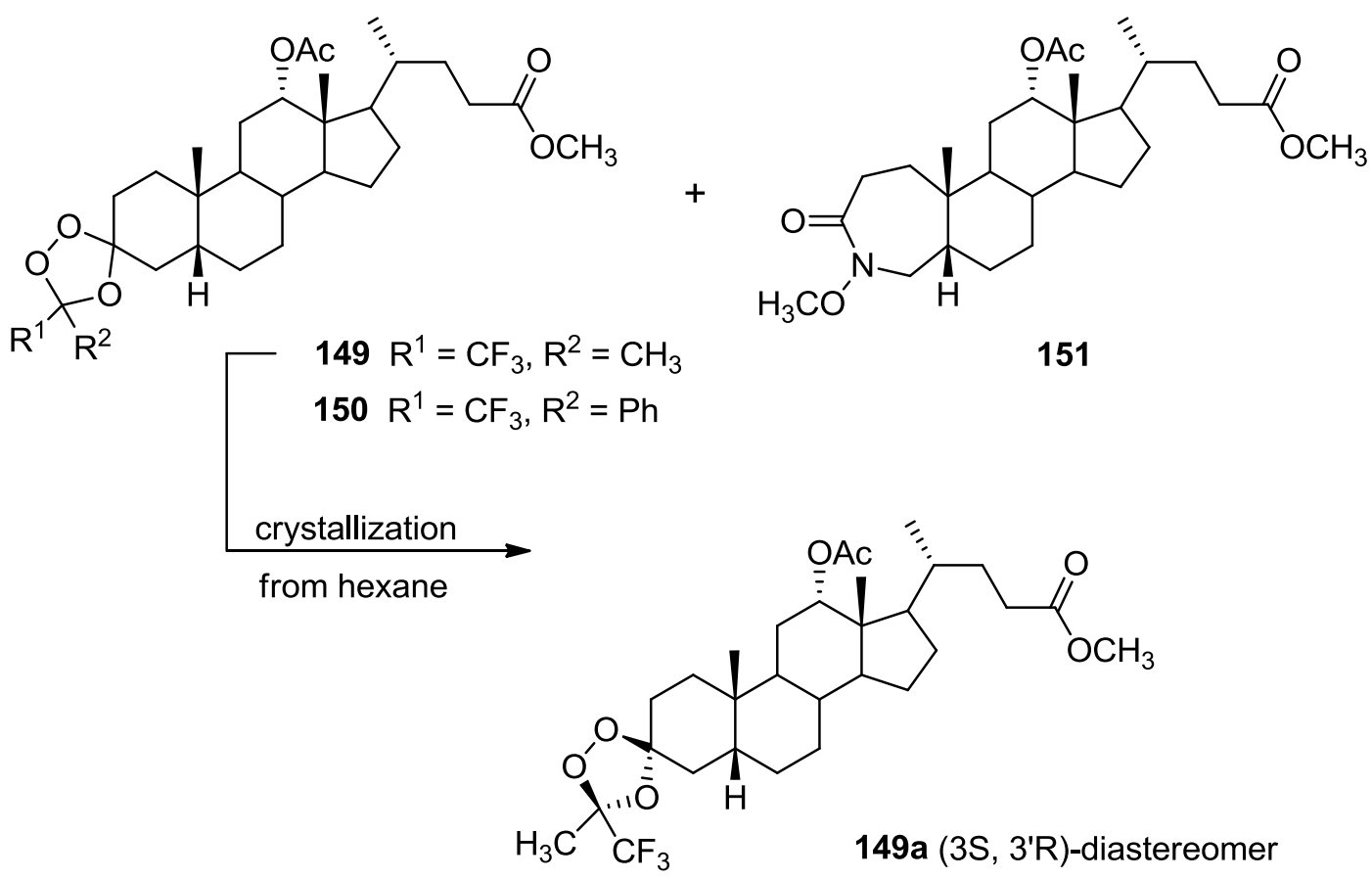

Scheme 32. Preparation of the ozonide 149a.

It was found that 1,2,4-trioxolane and 1,2,4,5-tetraoxane show a similar pharmacology profile against malarial parasites. ${ }^{59}$ In order to compare the antimalarial potency of different steroidal peroxides in vitro against $P$. falciparum, they carried out the synthesis of 1,2,4,5-tetraoxanes 153 and 154 via acid-catalyzed 
condensation of 152 with acetone and $\mathrm{CF}_{3} \mathrm{C}(\mathrm{O}) \mathrm{CH}_{3}$ (Scheme 33). The yields were $37 \%$ and $44 \%$, respectively. Trifluoromethylated 1,2,4,5-tetraoxane showed good results against the chloroquine-resistant CQR-strain K1 of $P$. falciparum, comparable to chloroquine, while the 1,2,4-trioxolane was better against the chloroquininesensitive CQS-strain T96.

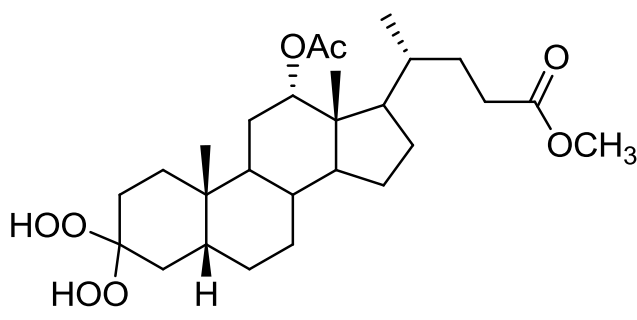

152

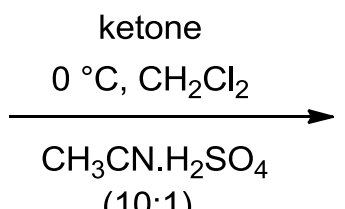

$(10: 1)$

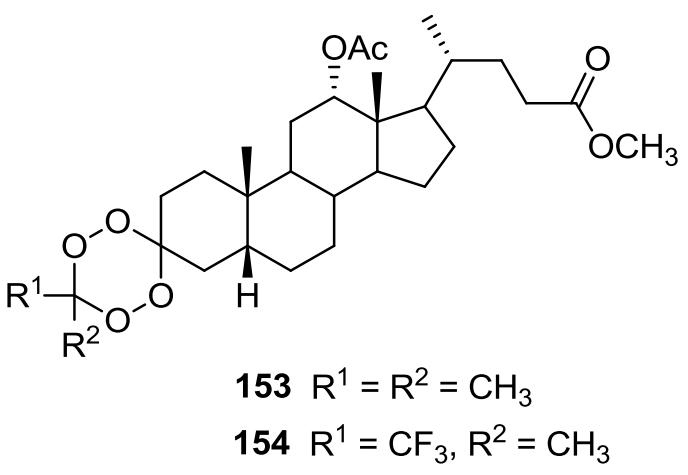

Scheme 33. Synthesis of tetroxanes 153, 154.

In 2018, Romero-Hernandez et al. $^{60}$ reported the straightforward preparation of novel conformationallyrestricted steroids from trans-androsterone and estrone with spirocyclic oxazolidin-2-one or 2-aminooxazoline motifs at C-17 as potential antiproliferative agents. The key step to synthesize these heterocycles on the steroidal backbone was access to an aminomethyl alcohol on C-17 and its transformation into transient isocyanates and thioureas. The synthesis of the aminoalcohol was accomplished in three steps from transandrosterone and four steps from estrone (Scheme 34).

Trans-androsterone was treated with trimethylsulfonium iodide under basic conditions to obtain epoxide 155 in a total stereoselective fashion via a Corey-Chaykovsky reaction. ${ }^{61}$ Nucleophilic opening of epoxide 155 was carried out using sodium azide in the presence of boric acid to form the azide $\mathbf{1 5 6}$ in quantitative yield; the absolute configuration of the new chiral carbon was assigned for compound $\mathbf{1 5 6}$ as the (S)-diastereomer. Azide 156 was reduced by catalytic hydrogenation to get the aminomethylalcohol 157, which in turn was treated with triphosgene, as a safe alternative to hazardous phosgene, in a $\mathrm{MeOH}-\mathrm{CH}_{2} \mathrm{Cl}_{2}$ mixture to obtain the transient isocyanate 158; this compound underwent a spontaneous cyclization involving the nucleophilic attack of the free $\mathrm{OH}$ to the heterocumulene, affording the spirooxazolidin-2-one (spirocarbamate) 159 (52\%); the use of $\mathrm{MeOH}$ as solvent led also to carbamate 160 as a by-product (25\%). The same reaction sequence was applied to form the estrone derived spirocarbamate 167; changing the nature of the A-ring (aromatic for estrone) might modify the biological properties and thus afford valuable structure-activity relationships. For this purpose, the free $\mathrm{OH}$ on $\mathrm{C}-3$ was first protected as its benzyl ether, and then, the functionalization of the C-17 was accomplished. Epoxide 163 was obtained in a stereoselective fashion, using KOtBu to form the sulfur ylid. The nucleophilic opening of $\mathbf{1 6 3}$ was carried out using sodium azide in DMF. The structure of azide $\mathbf{1 6 4}$ obtained by single crystal X-ray diffraction showed the configuration of C-17 as (S). Reduction of azide 164 under catalytic hydrogenation conditions also eliminated the benzyl group at C-3, giving amine 165 in a $77 \%$ yield after four steps. Reaction between 165 and triphosgene gave isocyanate 166, which was not isolated and spontaneously gave the final compound 167 and the by-product 168 in a 3:1 ratio (Scheme 34). 


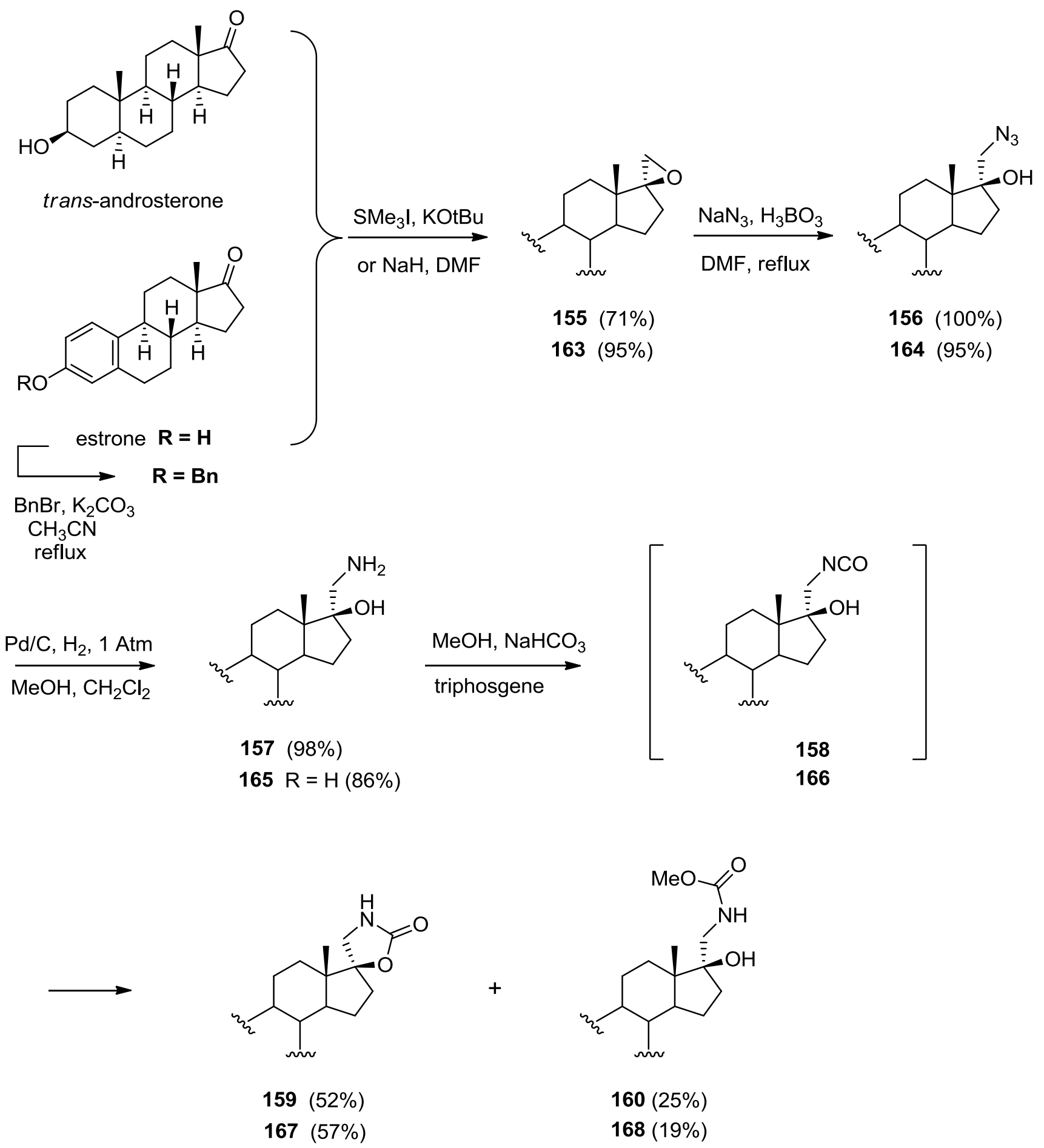

Scheme 34. Synthesis of oxazolidin-2-ones 159-167 from trans-androsterone and estrone.

Aminoalcohols from trans-androsterone and estrone were also used to obtain 2-aminooxazolines. Derivatives 157 and 165 were treated with different isothiocyanates (butyl, cyclohexyl and phenyl) under basic conditions, giving thioureas 161 and 169. The cyclodesulfurization reaction of thioureas promoted by yellow $\mathrm{HgO}$ afforded 2-aminooxazolines 162 and 170 with good to excellent yields (Scheme 35). Compounds 156-162 and 164-170 were tested as potential antiproliferative agents, and the order of activity was found to be aminooxazoline > spirocarbamate $>$ thiourea. The lead compounds, bearing a spiranic aminooxazoline motif on an estrone backbone, exhibited $\mathrm{GI}_{50}$ values in the low micromolar to submicromolar range (0.34-1.5 ? $\left.\mathrm{M}\right)$, 
with particular increase in activity against drug-resistant cell lines compared to other steroidal chemotherapeutic agents (Abiraterone and Galeterone).

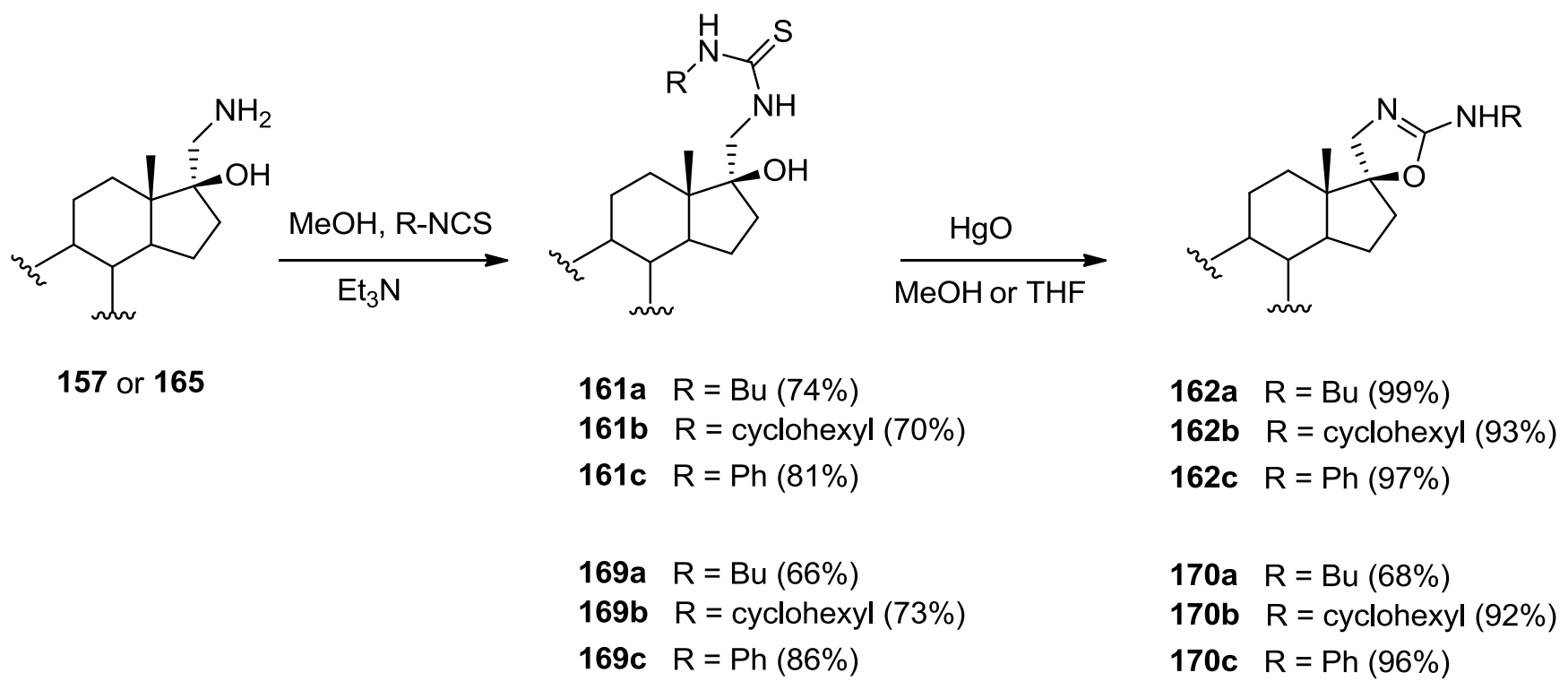

Scheme 35. Synthesis of 2-aminooxazolines 162, 170 from trans-androsterone and estrone.

\section{Synthesis of Heterocyclic Steroidal Analogues}

In 2015, Palanisamy et al. ${ }^{62}$ synthesized and investigated the antimicrobial, antituberculosis, and antitumor activity of some new pyrazole-, isoxazole-, pyrimidine- and benzodiazepine derivatives containing 3-(hydroxymethylene)-2,3-dihydrothiopyrano[3,2-c]thiochromen-4(5H)-one (173) and 2,3,5,6-tetrahydro-3-(hydroxymethylene) 4H-thiopyrano [3,2-d][1]benzothiepin-4-one (174) moieties. Preparation of the pyrazole, isoxazole, pyrimidine, and benzodiazepine derivatives was performed following the synthetic route described in Scheme 36.

The starting ketones 171 and 172 were prepared following the reported method. ${ }^{63}$ The starting key intermediates 3-(hydroxymethylene)-2,3-dihydrothiopyrano[3,2-c]thiochroman-4(5H)-one 173 and 2,3,5,6tetrahydro-3-(hydroxymethylene)4H-thiopyrano[3,2-d][1]benzothiepin-4-one 174 were obtained reacting ethyl formate with 171 and 172. Condensation of compounds 173 and 174 with phenylhydrazine hydrochloride, hydrazine hydrochloride, hydroxylamine hydrochloride, urea, thiourea, o-phenylenediamine, and 1,2-diphenylethane-1,2-diamine afforded the target series 175-188 (Scheme 36). The results obtained clearly revealed that the 1,2-diphenylene-1,2-diamine substituted 2,3-dihydrothiopyrano[3,2-c]thiochromen4(5H)-one 187 and 2,3,5,6-tetrahydro-4H-thiopyrano[3,2-d][1]benzothiepin-4-one derivatives 188 exhibited better antimicrobial activity than their counterparts. Similarly compounds $\mathbf{1 8 5}$ and 188 displayed more antimicrobial, antituberculosis, antitumor, and DNA cleavage activity compared to the other derivatives. In general, the benzodiazepine analogues 185-188 exhibited higher activity than the pyrazole, isoxazole, and pyrimidine analogues. 
<smiles>O=c1ncc2c([nH]1)C1CSc3ccccc3C1SC2</smiles><smiles>CC12CSc3ccccc3C1SCc1cnoc12</smiles>

$\mathrm{n}=1,179$

$\mathrm{n}=2,180$
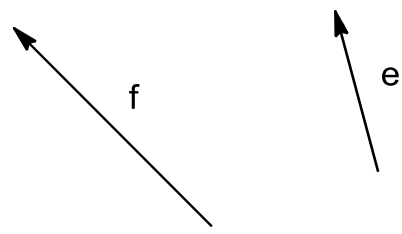<smiles>c1ccc2c(c1)SCC1c3[nH]ncc3CSC21</smiles>

$\mathrm{n}=\mathbf{1 , 1 7 7}$

$\mathrm{n}=2,178$

$\mathrm{n}=1, \mathbf{1 8 1}$

d<smiles>O=C1CCSc2ccccc21</smiles>

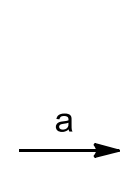

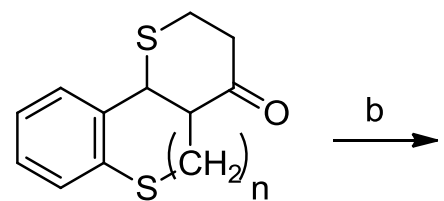<smiles>O=CC1=CCC2(CCCCC2)C(=O)C1=O</smiles><smiles>CCC</smiles><smiles>CSc1ccccc1C1C=C(c2ccccc2)C2=C1CCC2</smiles>

$\mathrm{n}=1$

$\mathrm{n}=1, \mathbf{1 7 1}$

$\mathrm{n}=2,172$

$$
\mathrm{n}=1, \mathbf{1 7 3}
$$$$
\mathrm{n}=2,174
$$

$\mathrm{n}=1,175$

$\mathrm{n}=2,176$

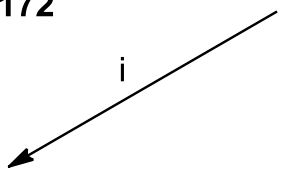<smiles>CP</smiles><smiles>CC1Nc2ccccc2N=CC2=C1C1CSc3ccccc3C1SC2</smiles>

$\mathrm{n}=1, \mathbf{1 8 5}$

$\mathrm{n}=2,186$

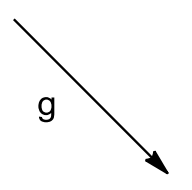<smiles>S=c1ncc2c([nH]1)C1CSc3ccccc3C1SC2</smiles>

$\mathrm{n}=1,183$

$\mathrm{n}=2,184$

Reaction conditions : (a) $\mathrm{ClCH}_{2} \mathrm{CH}_{2} \mathrm{COOH} / \mathrm{NaOH}$, PPA; (b) NaOEt, dry toluene, $\mathrm{HCOOC}_{2} \mathrm{H}_{5}$;

(c) $\mathrm{C}_{6} \mathrm{H}_{5} \mathrm{NHNH}_{2} \cdot \mathrm{HCl}$, EtOH; (d) $\mathrm{NH}_{2} \mathrm{NH}_{2} . \mathrm{HCl}, \mathrm{EtOH}$; (e) $\mathrm{NH}_{2} \mathrm{OH} . \mathrm{HCl}$, EtOH; (f) urea, $\mathrm{CH}_{3} \mathrm{COOH}$;

(h) o-phenylenediamine, $\mathrm{CH}_{3} \mathrm{COOH}$; (i) 1,2-diphenylethane-1,2-diamine, $\mathrm{CH}_{3} \mathrm{COOH}$.

Scheme 36. Synthesis of heterocyclic steroidal analogues.

\section{Conclusions}

The present review offers an up-to-date literature on the latest syntheses of steroidal derivatives containing heterocycles reported during the last years. Several of these syntheses may be useful, and in most cases reporting the cytotoxicity of the tested compounds, there seems to be a link to the incorporation of heterocyclic ring into the steroid moiety. In addition, some reports verified the importance of the presence of heterocyclic moieties as pharmacophores for the activity against cancer cell lines.

Overall, the interest in steroids and related compounds continue to expand given the diversity of structure and emerging bioactivity inherent in this compound class. 


\section{Acknowledgements}

This work has been financially supported by the CNRS and the Ministère de l'Enseignement Supérieur et de la Recherche.

\section{References}

1. Zeelen, J.F. Medicinal chemistry of steroids; Elsevier: Amsterdam, Netherlands, 1990.

2. Trager, L. F. Steroidhormone; Springer: Berlin, 1977.

3. Biellmann, J. F. Chem. Rev. 2003, 103, 2019.

http://doi.org/10.1021/cr020071b

4. Nising, C. F.; Bräse, S. Ang. Chem. Int. Ed. 2008, 47, 9389.

https://doi.org/10.1002/anie.200803720

5. Hanson, J. R. Nat. Prod. Reports 2010, 27, 887.

https://doi.org/10.1039/C001262A

6. Lewis, D. F. V.; Jacobs, M.; Dickins, M. Drug Discov. Today 2004, 9, 530.

https://doi.org/10.1016/S1359-6446(04)03115-0

7. Imtiyaz, H. L.; Khaliquz, Z. K.; Bharat, I. F.; Fida, H. Steroids 2013, 78, 945.

https://doi.org/10.1016/i.steroids.2013.05.015

8. Zhungietu, G. I.; Dorofeenko, G. N. Russ. Chem. Rev. 1967, 36, 24.3

https://doi.org/10.1070/RC1967v036n01ABEH001581

9. Li, Y.; Huang, J.; Liu, J.L.; Yan, P. Y.; Liu, H.; Sun, Q. Steroids 2011, 76, 1615.

https://doi.org/10.1016/i.steroids.2011.10.003

10. Rafat, M. M.; Wagnat, W. W.; Gamal, A. E.; Rehab, M. S. A. Steroids 2012, 77, 1560.

https://doi.org/10.1016/j.steroids.2012.09.004

11. Dwipen, K.; Rupak, K. S.; Ratul, S.; Nabin, C. B.; Jadab, C. S. Steroids 2013, 78, 321.

https://doi.org/10.1016/i.steroids.2012.12.003

12. Ranju, B.; Pratap, C. A. Steroids 2012, 77, 552.

https://doi.org/10.1016/i.steroids.2012.01.020

13. Duha, C. Y.; Loa, I. W.; Wang, S. K.; Dai, C. F. Steroids 2007, 72, 573.

https://doi.org/10.1016/i.steroids.2007.03.010

14. Ibrahim-Ouali, M.; Santelli M. Steroids 2006, 71, 1025.

https://doi.org/10.1016/i.steroids.2006.09.006

15. Hanson, J. R. Steroids: partial synthesis in medicinal chemistry. Nat. Prod. Rep. 2006, 23, 100. https://doi.org/10.1039/B512848J

16. Chen, S. J.; Cui, J. G.; Li, Y.; Fan, L. H. Chin. J. Org. Chem. 2011, 187.

http://sioc-journal.cn/Jwk yihx/EN/Y2011/V31/I02/187

17. Zhang, X. J.; Cui, J. G.; Li, Y.; Chen, S. J. Chin. J. Org. Chem. 2010, 30, 655.

http://sioc-journal.cn/Jwk yihx/EN/Y2010/V30/105/655

18. Stulov, S. V.; Misharin A. Y. Chem. Heterocycl. Compd. 2013, 48, 1431.

https://doi.org/10.1007/s10593-013-1158-8

19. Ma, B.; Xiao, Z. Y.; Chen, Y. J.; Lei, M.; Meng, Y. H.; Guo, D. A. Steroids 2013, 78, 508.

https://doi.org/10.1016/i.steroids.2013.02.007 
20. Guo, H.; Zhang, G. L.; Zhang, T., He, X. R.; Wu, Z. Y.; Xiao, Y. L.; Pan, Y.; Qiu, G.; Liu, P.; Hu, X. Eur. J. Med. Chem. 2011, 46, 3662.

https://doi.org/10.1016/i.ejmech.2011.05.030

21. Huang, L. H.; Zheng, Y. F.; Lu, Y. Z.; Song, C. J.; Wang, Y. G.; Yu, B.; Liu, H. M. Steroids 2012, 77, 710. https://doi.org/10.1016/j.steroids.2012.03.002

22. Kovács, D.; Mótyán, G.; Wölfling, J.; Kovács, I.; Zupkó, I.; Frank, É. Bioorg. Med. Chem. Lett. 2014, 24, 1265.

https://doi.org/10.1016/i.bmcl.2014.01.069

23. Dutta, M.; Saikia, P.; Gogoi, S.; Boruah, C. R. Steroids 2013, 78, 387.

https://doi.org/10.1016/i.steroids.2013.01.006

24. Shekarrao, K.; Nath, D.; Kaishap, P. P.; Gogoi, S.; Boruah, C. R. Steroids 2013, 78, 1126.

https://doi.org/10.1016/i.steroids.2013.08.002

25. Shekarrao, K.; Duarah, A.; Bora, T. C.; Gogoi, S.; Boruah, C. R. Steroids 2012, 77, 1438.

https://doi.org/10.1016/i.steroids.2012.08.008

26. Abad, Ali; Mohd, A.; Parvez, A.; Mohammad, J. A.; Mohd, A. S.; Rizwan, H. K.; Shabbir Ahmad, S. J. Bioorg. Chem. 2017, 73, 83.

http://dx.doi.org/10.1016/j.bioorg.2017.06.001

27. Callow, R.K.; James, V.H.T. J. Chem. Soc. 1956, 927, 4744.

https://doi.org/10.1039/JR9560004744

28. Zhang, B. L.; Zhang, E.; Pang, L. P.; Song, L. X.; Li, Y. F.; Yu B.; Liu, H. M. Steroids 2013, 78, 1200. https://doi.org/10.1016/i.steroids.2013.07.006

29. Siddiqui, A. U.; Rao, V. U. M.; Maimirani, M, Siddiqui, A. H. J. Heterocycl. Chem. 1995, 32, 353. https://doi.org/10.1002/jhet.5570320159

30. Elmegeed, G. A.; Khalil, W. K. B.; Mohareb, R. M.; Ahmed, H. H.; Abd-Elhalim, M. M.; Elsayed, G.H. Biorg. Med. Chem. 2011, 19, 6860.

https://doi.org/10.1016/i.bmc.2011.09.033

31. Zhang, B. L.; Song, L. X.; Li, Y. F.; Zhang, E.; Guo, Y. Z.; Liu, H. M. Steroids 2014, 80, 92.

https://doi.org/10.1016/i.steroids.2013.12.003

32. Wu, J.; Xia, H. G.; Gao, K. Org. Biomol. Chem. 2006, 4, 126.

https://doi.org/10.1039/B514635F

33. Singh, R.; Thota, S.; Bansal, R. ACS Chem. Neurosci. 2018, 9, 272.

https://doi.org/10.1021/acschemneuro.7b00303

34. Singh, R.; Bansal, R. ACS Chem. Neurosci. 2017, 8, 186.

https://doi.org/10.1021/acschemneuro.6b00313

35. Banday, A. H.; Mir, B. P.; Lone, I. H.; Suri, K. A.; Kumar, H. M. Steroids 2010, 75, 805.

https://doi.org/10.1016/i.steroids.2010.02.014

36. Mohareb, R. M.; Samir, E. M.; Halim P. A. Bioorg. Chem. 2019, 83, 402.

https://doi.org/10.1016/i.bioorg.2018.10.067

37. Han, Y.; Tang, W. Q.; Yan, C. G. Tetrahedron Lett. 2014, 55, 1441.

https://doi.org/10.1016/i.tetlet.2014.01.043

38. Banday, A. H.; Shameem, S. A.; Jeelani, S. Steroids 2014, 92, 13.

https://doi.org/10.1016/i.steroids.2014.09.004

39. Ivany, Z.; Wolfing, J.; Gorbe, T.; Szecsi, M.; Wittmann, T.; Schneider, G. Steroids 2010, 75, 450.

https://doi.org/10.1016/i.steroids.2010.02.013 
40. Wölfling, J.; Oravecz, E. A.; Ondré, D.; Mernyák, E.; Schneider, G.; Tóth, I. Steroids 2006, 71, 809. https://doi.org/10.1016/j.steroids.2006.05.011

41. Cui, J.; Liu, L.; Zhao, D.; Gan, C.; Huang, X.; Xiao, Q.; Qi, B.; Yang, L.; Huang, Y. Steroids 2015, $95,32$. https://doi.org/10.1016/i.steroids.2015.01.002

42. Abad, A.; Mohd, A.; Hena, K.; Ashraf, M.; Mohd, A. S.; Mohamma, O.; Shamsuzzaman. RSC Adv., 2015, 5, 75964.

https://doi.org/10.1039/C5RA11049A

43. Elmegeed, G. A.; Yahya, S. M.M.; Abd-Elhalim, M. M.; Mohamed, M. S.; Mohareb, R. M.; Elsayed, G. H. Steroids 2016, 115, 80.

https://doi.org/10.1016/i.steroids.2016.08.014

44. Vitellozzi, L.; McAllister, G. D.; Genski, T.; Taylor, R. J. K. Synthesis 2016, 48, 48. https://doi.org/10.1055/s-0035-1560353

45. Achmatowicz, O.; Bukowski, P.; Szechner, B.; Zwierzchowska, Z.; Zamojski, A. Tetrahedron 1971, 27, 1973.

https://doi.org/10.1016/S0040-4020(01)98229-8

46. Kametani, T.; Tsubuki, M.; Furuyama, H.; Honda, T. J. Chem. Soc., Perkin Trans. 1 1985, 557. https://doi.org/10.1039/P19850000557

47. Matsuya, Y.; Yamakawa, Y.-i.; Tohda, C.; Teshigawara, K.; Yamada, M.; Nemoto, H. Org. Lett. 2009, 11, 3970.

https://doi.org/10.1021/ol901553w

48. Mohammed Kolo, A.; İpek, E.; Çapan, i.; Servi, S. J. Het. Chem. 2018, 55, 492.

https://doi.org/10.1002/ihet.3070

49. Mótyán, G.; Mérai, L.; Kiss, M. A.; Schelz, Z.; Sinka, I.; Zupkó, I.; Frank, É. Beilstein J. Org. Chem. 2018, 14, 2589-2596.

https://doi.org/10.3762/bjoc.14.236

50. Kovács, D.; Wölfling, J.; Szabó, N.; Szécsi, M.; Minorics, R.; Zupkó, I.; Frank, É. Eur. J. Med. Chem. 2015, 98, 13-29.

https://doi.org/10.1016/i.ejmech.2015.05.010

51. Mótyán, G.; Kovács, F.; Wölfling, J.; Gyovai, A.; Zupkó, I.; Frank, É. Steroids 2016, 112, 36. https://doi.org/10.1016/i.steroids.2016.04.014

52. Kotovshchikov, Y. N.; Latyshev, G. V.; Beletskaya, I. P.; Lukashev N. V. Synthesis 2018, 50, 1926. https://doi.org/10.1055/s-0036-1591896

53. Yamansarov, E. Yu.; Kazakova, O. B.; Medvedeva, N. I.; Kazakov, D. V.; Kukovinets, O. S.; Tolstikov, G. A. Russian J. Org. Chem. 2014, 50, 1043. https://doi.org/10.1134/S1070428014070197

54. Gavaskar, D.; Suresh Babu, A. R.; Raghunathan, R.; Dharani, M.; Balasubramanian, S. Steroids 2016, 109, 1.

https://doi.org/10.1016/i.steroids.2016.02.010

55. Gavaskar, D.; Suresh Babu, A. R.; Raghunathan, R.; Dharani, M.; Balasubramanian, S.; J. Organomet. Chem. 2014, 768, 128.

https://doi.org/10.1016/j.jorganchem.2014.06.015

56. Yamansarova, E. Y.; Kazakova, D. V.; Medvedeva, N. I.; Khusnutdinova, E. F.; Kazakova, O. B.; Legostaeva, Y. V.; Ishmuratova, G. Y.; Huong, L. M.; Hong Ha, T. T.; Huong, D. T.; Suponitsky, K. Y. Steroids 2018, 129, 17. 
https://doi.org/10.1016/i.steroids.2017.11.008

57. Opsenica, D.; Pocsfalvi, G.; Jurani, Z.; Tinant, B.; Declercq, J. P.; Kyle, D. E.; Milhous, W. K.; Šolaj B. A. J. Med. Chem. 2000, 43, 3274.

http://doi.org/10.1021/im000952f

58. Griesbaum, K.; Liu, X.; Kassiaris, A.; Scherer M. Liebigs Ann. 1997, 1381. https://doi.org/10.1002/ilac.199719970715

59. Bousejra-El Garah, F.; Wong, M.H.-L.; Amewu, R. K.; Muangnoicharoen, S.; Maggs, J. L.; Stigliani, J. L.; Park, B.K.; Chadwick, J.; Ward, S.A.; O’Neill, P.M. J. Med. Chem. 2011, 54, 6443.

http://doi.org/10.1021/jm200768h

60. Romero-Hernandez, L. L.; Merino-Montiel, P.; Meza-Reyes, S.; Vega-Baez, J. L.; Lopez, O.; Padron, J. M.; Montiel-Smith, S. Eur. J. Med. Chem. 2018, 143, 21.

https://doi.org/10.1016/i.ejmech.2017.10.063

61. Maltais, R.; Tremblay, M.R.; Poirier, D. J. Comb. Chem. 2000, 2, 604.

https://doi.org/10.1021/cc0000242

62. Palanisamy, P.; Sudhakar, S.; Kumaresan, S. World J. Pharm. Sci. 2015, 2321. http://www.wjpsonline.org/

63. Kumaresan, S.; Ramadas, S. R. Sulfur Lett., 1984, 2, 31.

https://doi.org/10.1080/03086648408077592

\section{Authors' Biographies}

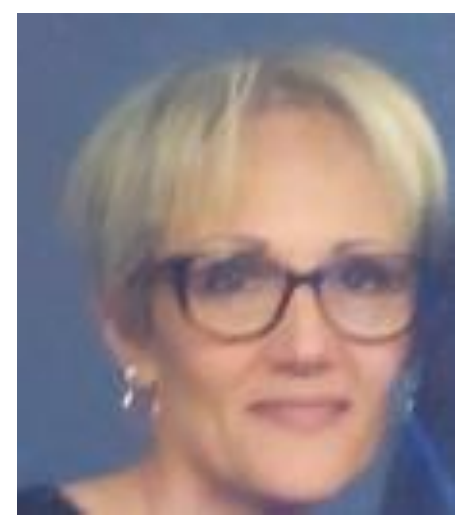

Malika Ibrahim-Ouali carried out her PhD under the supervision of Professor Gramain in Clermont-Ferrand (France) in 1996. The work was focused on the synthesis of alkaloids. She was a postdoctoral fellow with Prof. Knochel in 1996 where she got her first training in organometallic chemistry. In 1997, she joined Professor H. P Husson's group at the ICSN (Paris) as a postdoctoral researcher. Since 1998, she is currently an assistant professor at Aix-Marseille University and her field of interest remains the total synthesis of natural compounds. 


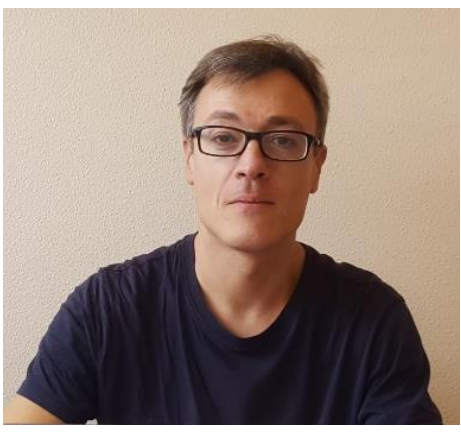

Frédéric Dumur received his PhD in chemistry in 2002 from the University of Angers (France) under the supervision of Professor Pietrick Hudhomme. After Post-Doctoral studies at the University of Groningen (The Netherlands), Reims Champagne-Ardennes (France) and Versailles Saint-Quentin-en-Yvelines (France), he joined the Faculty of Sciences at Aix-Marseille University in 2008, where he is currently working as an Associate Professor. His research interests include the synthesis of phosphorescent dopants for OLEDs and photoinitiators of polymerization. He co-authored about 225 publications and 5 book chapters. 